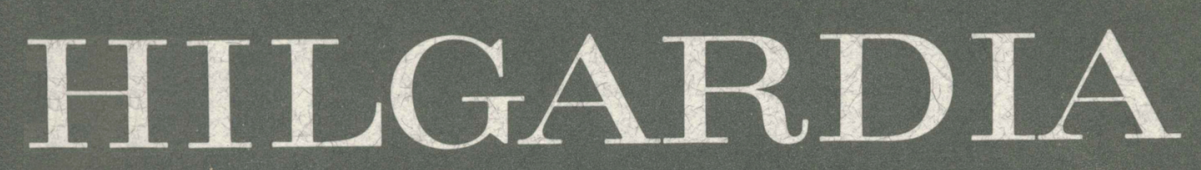

A JOURNAL OF AGRICULTURAL SCIENCE PUBLISHED BY THE CALIFORNIA AGRICULTURALEXPERIMENTSTATION

Volume 41, Number $12 \cdot$ October, 1972

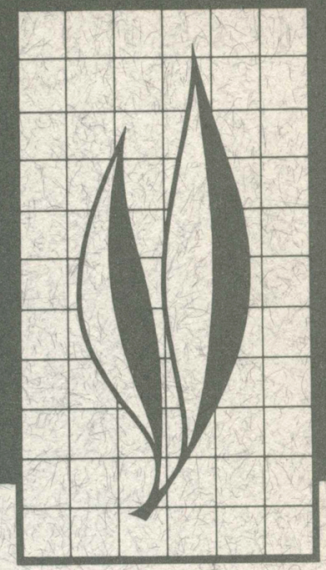

\title{
Effects of Gamma Radiation on the
}

\section{Biology and Population Suppression of the Two-spotted Spider Mite, Tetranychus urticae Koch}

Richard D. Nelson and Eugene M. Stafford 


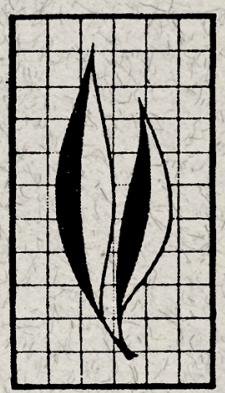

Some biological effects of gamma radiation on the two-spotted mite, Tetranychus urticae Koch were determined. A substerilizing dose given to a male subsequently mated to a normal female caused sterility in the $F_{1}$ female progeny. LD50/10 values for adult males and females were established at 90 and 110 krads, respectively. Eggs were more radioresistant as they aged; 3,000 to 3,200 rads were lethal to all one- and two-day-old eggs, while most all threeand four-day-old eggs hatched after an exposure to 11,500 rads. Male protonymphs, deutonymphs, and adults were all rendered sterile, and eggs and larvae were killed with $20 \mathrm{krads}$. A dose of $100 \mathrm{krads}$ did not appear to cause sperm inactivation in males. The tests supported the belief that males undergo multiple matings. The eggs of about 10 per cent of the females undergoing secondary matings were successfully fertilized by more than one male. A sterilizing dose for males did not detrimentally alter mating competitiveness or longevity.

Control of this species in strawberries was attempted using the sterile-male technique. Field release of both sexes caused plant damage due to additional feeding activity. An all-male colony was obtained from isolated virgin females, but not enough males could be reared, sterilized, and released to reduce the endemic field population.

\section{THE AUTHORS:}

Richard D. Nelson, formerly graduate student, Department of Entomology, Davis, is Assistant Director of Research, Driscoll Strawberry Associates, Inc., Watsonville, California.

Eugene M. Stafford is Professor of Entomology and Entomologist in the Experiment Station, Davis. 


\section{Effects of Gamma Radiation on the Biology and Population Suppression of the Two-spotted Spider Mite, Tetranychus urticae $\mathrm{Koch}^{1}$}

\section{INTRODUCTION}

Chemical control of Tetranychus urticae Koch in strawberries is hampered by the harvesting schedule of every three to five days, and by genetic resistance due to selective pressure from miticides suitable for such a schedule. Thus, sterile-male techniques present an appealing alternative.

The use of sterile male insects has been accepted as one means of pest control since the theory was introduced in 1955 by Knipling. Sterility, the inability to produce offspring, may be induced chemically or by exposure to ionizing radiation. With Knipling's sterile-male technique large numbers of insects are reared, sterilized, and released to live out their lives in competition with nonsterilized members of their species. Matings between normal female and sterilized male insects are nonproductive or produce significantly fewer progeny, depending on the reproductive physiology and habits of the species.
The objectives of this study were (1) to determine some of the basic biologic effects of ionizing radiation on the twospotted mite, Tetranychus urticae Koch and (2) to study the effects of releasing sterile individuals into natural populations of mites in strawberry fields.

In California alone, approximately $\$ 2$ million is spent annually for the attempted control of $T$. urticae Koch (two-spotted mite) in strawberries.

The attempt in this study to control a population of $T$. urticae Koch with the sterile-male technique was challenging, because (1) the female is parthenogenetic and can therefore produce normal male offspring even though mated to a sterile male; and (2) at all postembryonic stages of development, the mite is a plant feeder. These two factors call for a delicate balance between numbers of sterile individuals released and economic levels of crop damage.

\section{LITERATURE REVIEW}

\section{Radiation theory and biological effects}

A concise review on the production of radiation and its interaction with biological material is given by Nelson (1968).

\section{Genetic and physiological} basis for sterility

Sterility (inability to produce offspring) may be caused by infecundity in females, sperm inactivation, aspermia, inability to mate, or dominant

${ }^{1}$ Submitted for publication January 16, 1970. 
lethal mutations in the reproductive cells of either sex. Sterility may be due to a combination of factors, as is the case with the adult female mite (i.e., dominant lethals are induced in eggs of certain maturity, and once having expelled these, the female becomes infecund). Examples of each of these methods are cited by LaChance, Schmidt, and Bushland (1967). Dominant lethal mutations in the male have proved to be the most successful means of sterilization thus far and will, for that reason, be discussed in some detail. Both electromagnetic radiations and particulate radiations such as neutrons (Baker and von Halle, 1954) and alpha particles (Clark, Rubin, and Fluke, 1957) have been shown to induce dominant lethal mutations in the chromosomes of insect sperm. The phrase "dominant lethal mutation" was introduced by Muller (1927) in his classic paper on the discovery of mutagenic effects of x-rays in Drosophila. A dominant lethal mutation normally does not affect the maturation of a treated cell into a gamete or the process of fertilization. A lethal mutation in but one of the gametes prevents the zygote from maturing to a normal reproductive entity. Although a lethal mutation may be expressed at any time in the life cycle, death usually occurs before hatching, as many vital developmental processes must be completed during embryological maturation. Cytogenetic studies indicate that death usually occurs before the blastoderm stage (LaChance, Schmidt, and Bushland, 1967).

Radiation-induced dominant lethal mutations are believed to arise as a result of chromosome breaks in the treated cell (LaChance, Schmidt, and Bushland, 1967; LaChance, 1967; LaChance, North, and Klassen, 1968). Point mutations may also result in a dominant lethal effect. However, this is difficult to prove, because these muta- tions may be minor and undetectable chromosome breaks. Most point changes will not result in lethality, but will be expressed as a heritable character in the $F_{1}$ progeny. Most mutations have proved to be detrimental rather than beneficial, and this should be expected when one considers the effects of a random change in a system that is already functioning well. Mutations are brought about by a change in the base sequences in the DNA chain, either from direct ionization or interaction with free radicals. These changes result from base ionization, "forbidden-pair" production, base change, or base deletion. A basic change in the structure of a chromosome will bring about permanent changes in the linear order of genes on that chromosome. When more than one chromosome is involved, such structural changes can influence the distribution of genes among the chromosomes of any one nucleus. These changes are reproduced at mitosis and meiosis, and are thus heritable.

A single break in a single chromosome is the ultimate in simplicity, but as one contends with numerous chromosomes per cell, numerous breaks per chromosome, and crossing-over during meiosis, the system becomes extremely complex. Such conditions can result in translocations, deletions, inversions, duplications and insertions, most of which are deleterious to the zygote formed from affected gametes. This subject is aptly discussed and described in Pizzarello and Witcofski (1967), as well as in many of the other general references cited by Nelson (1968).

\section{Radiosensitivity and influencing factors}

The table of sterilizing doses compiled by LaChance, Schmidt, and Bushland (1967) shows that sensitivity among insects varies tremendously. Only 2,500 $\mathrm{rads}^{2}$ were required to steril-

\footnotetext{
${ }^{2} \mathrm{~A}$ rad is that amount of ionizing radiation causing deposition of $100 \mathrm{ergs}$ of energy per gram of absorber. A krad is 1,000 rads.
} 
ize five-day old screwworm pupae, Cochliomyia hominivorax (Cocquerel), while 50,000 rads were needed to induce sterility in mature navel orangeworm pupae, Paramyelois transitella (Walker). Many hypotheses have been advanced to explain differential sensitivity, and many have been disproven; only a few have stood the test of critical examination. Few texts have considered all aspects of this subject in much detail. In addition to previously mentioned references are reviews by Evans (1962), Grosch (1962), LaChance, Schmidt, and Bushland (1967), LaChance, North, and Klassen (1968), Mandl (1964), Virkki (1965), and von Borstel (1963). The proceedings of a symposium (Sobels, 1963) on repair from genetic radiation damage and differential radiosensitivity in germ cells is also useful, as are proceedings of a symposium chaired by Sparrow (1961) at the Brookhaven National Laboratory, which deals specifically with the fundamental aspects of radiosensitivity. Various factors affecting radiosensitivity are:

\section{Kinds of radiation and the manner in which they are delivered.}

Types of radiation. Various types deposit their energy in different ways depending on the mass, charge, and velocity of the ionizing particle. The linear energy transfer (LET) or rate of energy dissipation along a particle track has a direct relationship to the relative biological efficiency (RBE) of a particular type of radiation.

Fractionation. This generally lessens the deleterious effects of radiation; that is, an organism is more sensitive to a single acute dose than to the same dose administered over an extended period of time. Restitution-the joining together of broken chromosomes into their original state-during the inter-radiation intervals may in part account for this phenomenon. Distribution of cells in various mitotic stages may be altered from their normal pattern after an initial exposure thus rendering them more resistant. Mandl (1964) has summarized the work of several investigators on this subject.

Dose rate. This is crucial, since each stage during gametogenesis is more or less susceptible than other stages; prolonged irradiation at low intensities may include and affect a large portion of the gametogenic cycle.

2. Chemical and physical characteristics of the organism.

Life stage. Adult insects are generally more radioresistant than younger stages. Early embryos of Habrobracon are killed with 165 rads, but the lethal dose for adults exceeds 100,000 rads (Grosch, 1965a). This phenomenon is interdependent with other influences.

Age. Baxter and Tuttle (1957) found that older adult Drosophila were more sensitive than younger individuals. Wharton and Wharton (1959) demonstrated that adult cockroaches, Periplaneta americana, become proportionately more sensitive with increasing age. Mitotic rate. Rapidly dividing cells are known to be more radiosensitive than those in a post-mitotic state. This phenomenon is obvious when one compares the LD 50 values for eggs of progressively older age. Very young embryos, consisting of rapidly dividing tissue, are usually more sensitive than the more mature embryos.

Nuclear size and DNA content. Sparrow (1962) states that the size of the nucleus in diploid species is of major importance in determining radiosensitivity of different plants. Species with big nuclei are very sensitive, those with small nuclei very resistant. $\mathrm{He}$ confirmed this by correlating radiosensitivity and nuclear volume in 23 species of plants. He also found a direct correlation between the DNA con- 
tent and the nuclear volume; that is, the larger nuclei also contained more DNA. More important than this was the amount of DNA per chromosome.

Chromosome size and number. A bigger chromosome will absorb more radiation, and the probability will be greater that part of it will be lost by random fragmentation. Sparrow (1962) established the fact that resistance increases with increased chromosome number by administering chronic radiation to a naturally occurring polyploid series in Chrysanthemum.

Location and type of centromere. Cells containing acrocentric chromosomes tend to be more sensitive than those having metacentric chromosomes. This becomes apparent when one considers the fate of the acentric fragment from an acrocentric chromosome. A break occurring next to the centromere would cause the genes of nearly the entire chromosome to be lost. Chromosomes which display a diffuse centromere are highly resistant compared to those having a normal centromere (Virkki, 1965). The diffuse centromere is spread out along the whole chromosome, so fragments are capable of metaphasic orientation and anaphasic movement. Both Hemiptera and Lepidoptera have diffuse centromeres which may account for the characteristic radioresistance exhibited by these orders.

Amount and distribution of heterochromatin. Heterochromatin (densely staining at interphase) is reported to be more breakable than euchromatin (densely staining at metaphase), but is not associated with what are considered the more important genes (Virkki, 1965). Therefore, the loss can be tolerated more readily than can genes associated with euchromatin.

Stage of gametogenesis. Von Borstel (1963) presents a fairly detailed discussion of the differential sensitivity of the meiotic stages during oogenesis and spermatogenesis of several species. Sobels (1963), and Wurgler, Ulrich and Schneider-Minder (1963) present information on variation in radio-sensitivity of meiotic stages in Drosophila. LaChance, Schmidt, and Bushland (1967), and Evans (1962) give good reviews as well. These workers generally concluded that chromosome aberrations are more readily induced during division stages. Using the meiotic cells of Trillium anthers, Sparrow (1962) showed that the highest frequency of fragments were observed after irridiation between diplotene and metaphase-I, while early post-meiotic interphase was the least sensitive stage. Both Drosophila and Habrobracon cells undergoing meiosis show greatest radiation sensitivity during the metaphase-I stage. It is also generally concluded that spermatids are highly sensitive as compared to mature spermatocytes. Factors which may account for this change in sensitivity within one cell cycle during meiosis include differences in water content, oxygen tension, contracted state of the chromosomes, protective chemicals at certain stages, and a greater capacity for restitution or rejoining during particular stages. There are considerably less data on radiosensitivity of division stages during mitosis, but the information available reveals that metaphase is once again the most sensitive stage for chromosome breakage in both plants and animals (Evans, 1962).

\section{Physical and physiological factors} to which the organism is subjected before, during, or after treatment.

Oxygen. The unique feature of the "oxygen effect" is its nearly biological universality-the one exception being intracellular structures which return to their normal state shortly after exposure. This effect is most pronounced with sparsely ionizing radiations, such 
as gamma and x-rays, and to a lesser extent with beta particles. Mandl (1964) reporting on work by Fritz and Niggle on Drosophila states that the degree to which anoxia influences radiation-induced dominant lethality depends upon the gametogenetic stage irradiated, the gas replacing air during exposure, and the pressure of the gas. Evans (1962) and Pizzarello and Witcofski (1967) discuss the oxygen effect and the various mechanisms by which the phenomenon is thought to operate.

Temperature. Results of several studies with both somatic and germinal tissue indicate that a reduced temperature during exposure often moderates radiation effects (Mandl, 1964). Whiting (1961) irradiated unfertilized Habrobracon oocytes at metaphase-I kept at high $\left(30^{\circ} \mathrm{C}\right)$ or low $\left(-3^{\circ}\right.$ to $\left.5^{\circ} \mathrm{C}\right)$ temperatures before, during, and after irradiation. A protective effect was observed when the oocytes were kept at a low temperature for eight hours before irradiation or for 40 minutes after treatment. Cold temperatures during irradiation (11/2 minutes) had no protective effect. Whiting discusses the possibility that the observed effects may be due to chromosome movement or oxygen stress, or both, as affected by the temperature, rather than the temperature per se. Evans (1962) refers to the work of Baker and Sgourakis who found that the induction of recessive lethals in Drosophila was temperaturedependent in the presence of oxygen, but was not in a nitrogen atmosphere. As temperature changes, it affects the rates of numerous physiological processes; therefore, it is unlikely that any one factor is responsible for the relation between temperature and abberation frequency.

Water content. Organisms in a highly dehydrated state are radioresistant compared to those having a high water con- tent. The indirect action of radiation on water to produce $\mathrm{OH}$ and $\mathrm{H}$ radicals, which may, in turn, undergo further reactions with hydrogen peroxide being the end product, may account for this phenomenon.

Chemical factors. Numerous chemical substances have been investigated for possible benefits against radiation. The thiols and disulfides, chemically related to cysteine, have been the most thoroughly investigated. Mandl (1964) reviewed the work of others concerning the effects of cysteamine and cysteine on Drosophila and Bombyx. No protection was afforded in either case, even though they were given the maximum tolerated dose of the chemicals. Lack of protection in insects may be due to their low toleration of these drugs. Pizzarello and Witcofski (1967) report on other drugs affording some protection. Included are antioxidants (vitamin $\mathrm{E}$ and alphatocopherols), which are active reducing agents capable of terminating the autooxidative chain reactions; cobalt, which can destroy hydrogen peroxide; and chelating agents (ethylene diaminetetra-acetic acid=EDTA), which can remove heavy metals from solutions that might be catalyzing peroxy freeradical reactions. Most of these chemical agents must be taken before exposure for protective action, and they are therefore of limited value as postirradiation therapy.

It seems obvious that one or two factors can hardly be responsible for the wide degree of radiosensitivity observed in the plant and animal kingdoms. It is a highly complex phenomenon which is dependent on numerous factors. Alexander (1965) postulates one dominating factor that accounts for high radioresistence in adult insects. Most cells in adult insects are in a post-mitotic condition, and little cell division is necessary to maintain life. Thus, the only way these cells can be destroyed is by 
an interphase death mechanism, which requires massive doses resulting in damage to some major metabolic process essential for life. Alexander (1965) states that death from irradiation in adult insects may be induced by an adverse physiological characteristic, such as change in permeability, so that some vital organ no longer discharges a function necessary to life.

\section{THE STERILE-MALE TECHNIQUE}

Three general reviews concerning the sterile-male technique include those by Proverbs (1969), LaChance, Schmidt, and Bushland (1967), and Grosch (1962). Two progress reports from the International Atomic Energy Agency are also useful (Lindquist, 1963; LaBrecque and Keller, 1965). Other articles include those by von Borstel (1963), and Stone (1963) from a symposium on the use and application of radioisotopes and radiation in the control of plant and animal insect pests. Comprehensive bibliographies have also been compiled by the International Atomic Energy Agency (1962, 1965, 1967).

The success encountered in the eradication of the screwworm fly has precipitated further research of this concept of pest control by scientists the world over. The sterilizing doses of ionizing radiation for over 60 species of arthropods, primarily in the orders Diptera, Coleoptera, and Lepidoptera with 20, 15, and 18 species respectively, are now known (LaChance, Schmidt, and Bushland, 1967).
Other more recent efforts of population control using the sterile-male technique have been reviewed by LaChance (1967), LaChance, Schmidt, and Bushland (1967), and Proverbs (1969). Programs with the Mediterranean fruit fly, Ceratitis capitata (Wiedemann); Mexican fruit fly, Anastrepha ludens Loew; codling moth, Carpocapsa pomonella (L.) ; and field cockchafer, Melolontha vulgaris (F.) have shown promising results. Field cage tests with the cabbage looper, Trichoplusia ni (Hubner) are also encouraging (Toba, et al., 1972).

The reasons that follow for failure of the sterile-male method are nearly as numerous as the number for which the technique has been attempted:

Laboratory and field strains are incompatible; individuals lack the vigor to disperse and seek out native females; rearing techniques, sterilization, or release methods reduce vigor or induce abnormal behavior; too few sterile individuals are released; weather is adverse during release; or field behavior of the species involved is not clearly understood.

\section{BIOLOGY AND TAXONOMY OF THE TWO-SPOTTED SPIDER MITE}

The first important step towards understanding the biology of this species occurred in the early 1920's when the male of the species was found to have the haploid number of chromosomes, while the female was diploid (Schrader, 1923). Helle and Boland (1967) using the aceto-orcein squash technique found three and six chromosomes in haploid and diploid eggs, respectively. Cagle
(1949) studied the life history in the laboratory (with concurrent field observations) and described various life stages, feeding characteristics, and mating habits. He studied the effects of temperature on the incubation period of the eggs and found that three days were required at $24^{\circ} \mathrm{C}$, while 21 days were needed at $11^{\circ} \mathrm{C}$. Minimum and maximum times for development of each life 
stage under varying temperature conditions were also investigated. The total time for development from hatching to adult varied from 5 to 20 days for males and 5 to 59 days for females. Average life span for adult males from 16 generations was 28 days, while that of the female was 22 days, as determined from a total of 11 generations. The sex ratio was found to slightly favor the females: fifty-four per cent was recorded in 1946 and 56 per cent in 1947.

Two years after Cagle's publication, Gasser (1951) reported additional information on morphology and anatomy. His biological information was much the same, except for the observed sex ratio of. two females to one male. The influence of nutrition, temperature, and photoperiod on diapause is summarized by Boudreaux (1963). Watson (1964) studied in some detail the effects of hostplant condition on population dynamics of the two-spotted mite. Other ecological aspects concerning tetranychid mites and their natural control were recently reviewed by Huffaker, Van de Vrie, and McMurtry (1969, 1970). Life tables for populations reared in plant-growth chambers were recently published (Laing, 1969).

Boudreaux (1958) studied the effects of relative humidity on egg laying, hatching, and survival in six species of spider mites. He found that under dry conditions ( 0 to 35 per cent relative humidity (RH)) Tetranychus telarius $(=T$. urticae) laid more eggs, lived longer, and had a greater $F_{1}$ survival rate than did those kept under wet conditions (95 to 100 per cent $\mathrm{RH}$ ). Boudreaux explained these results on the basis that mites in a dry atmosphere are able to ingest a greater amount of food and can utilize or concentrate more of it through elimination of body moisture by evaporation from the cuticle. Mites in a high-humidity environment are unable to lay as many eggs, because cuticular evaporation is reduced; this limits the amount of feeding and in turn influences accumulation of nutrients needed for egg production. He also observed that mites in the dry atmosphere were larger, the average weight of a female in a dry environment being 18.3 $\mu \mathrm{g}$ as opposed to $14.6 \mu \mathrm{g}$ for those in a wet atmosphere. Boudreaux states that this was probably due to having several nearly full-size eggs developing together in the oviducts of the mites in a dry atmosphere.

McEnroe (1961) found that the bulk of water excretion by this mite occurs when fluids are bypassed to the hindgut, were small ions may be absorbed and water rapidly eliminated. Blauvelt (1945) provided the needed morphological descriptions for McEnroe to suggest that oscillating movements of the mandibular plate (stylophore) due to its structural relationship with the peritremes, could result in an active ventilation of the tracheal system. McEnroe thus discredits Boudreaux's reference to cuticular evaporation, especially in light of the Gibbs and Morrison (1959) study which demonstrated a lipid layer in the cuticle of $T$. urticae. If, in fact, the cuticle was very permeable (as suggested by Boudreau) it would impose a water stress on the over-wintering form which does not feed and possesses no visible fecal material in the midgut.

An inverse relationship between reproductive rate and relative humidity does not exist in all Tetranychid mites, for Nickel (1960) found that T. desertorum Banks has a higher rate of reproduction and a faster rate of development when exposed to high (85 to 90 per cent $\mathrm{RH}$ ) rather than low relative humidity. Although this species laid more eggs at low humidity, the net reproductive rate, designated as $R_{0}$ by Andrewartha and Birch (1954), was lower at the low humidity level. Nickel proposes that this is due to a higher immature mortality and shorter adult longevity at low humidity. 
Related studies include those of Dosse and Langenscheidt (1964) who studied the morphology, biology, and histology of hybrid progeny from T. urticae-cinnabarinus matings. In an effort to resolve the taxonomic status of two members of the two-spotted mite complex, Keh (1952) made several crosses which yielded valuable biological information. Kensler and Streu (1967) conducted a biological and toxicological study on three strains of the two-spotted mite, and Lehr and Smith (1957) investigated the reproductive capacity of three strains of this species.
The taxonomic status of the twospotted mite complex has long been an area of confusion and controversy. It is not within the scope of this paper to review comprehensively the many publications concerning this subject. For this study, we will use the findings of Boudreaux and Dosse (1963). According to their work, Tetranychus urticae Koch is the valid name for the two-spotted mite. A list of synonomies include $T$. telarius (L.) T. althaeae Hanstein, $T$. bimaculatus Harvey, Trombidium telarium (L.), Trombidium tiliarium Hermann, and Acarus telarius L.

\section{MATERIALS AND METHODS}

\section{Radiation source}

The Mark II cobalt-60 irradiator used in this study was designed by $\mathrm{O}$. Kuhl and others of the Brookhaven National Laboratory, Upton, New York. Its basic components include a stainless steel well, elevator and guides, three watertight irradiation chambers, water demineralizer, facility for temperature control in the chambers, oxygen exchange system, and numerous control systems. The original source strength was 43,000 curies of cobalt-60. A detailed description and schematic diagram of the radiation facility may be found in articles by Romani et al. (1962, 1963).

All experiments were conducted at ambient temperature $\left(22 \pm 2^{\circ} \mathrm{C}\right)$ with the oxygen exchange system in operation to prevent ozone accumulation in the irradiation chambers. When exposing mites, cages containing specimens were placed upright on the center shelf of a rack that fitted into the irradiation chamber. Slight variations in dose that could have occurred in different parts of the chamber were thereby minimized.

\section{Dosimetry}

Experimental data in radiation studies are no better than the reliability and reproducibility of the various doses used. The ferrous sulfate (Fricke) dosimeter had been used for calibration of the gamma source (Romani et al. 1963). Standard procedures were followed in preparing the ferrous sulfate stock solutions, and the generally accepted "G" value of 15.6 was assumed for all calculations (Romani et al. 1963). Thermoluminescence dosimetry was utilized to verify the values obtained by the Fricke method. The dose rate during the course of the experiments ranged from 21.32 minutes per 100 krads to 23.56 minutes per 100 krads (September, 1967, to June, 1968). The dose rate for all experiments conducted at the 76-centimeter position was 156.90 minutes per 100 krads.

\section{Laboratory studies}

Rearing procedures. The original stock (nonresistant strain) for the colony of mites came from Stauffer Chemical Company, Mountain View, California. The colony was maintained on pinto bean (Phaseolus vulgaris) foliage in an environmental growth chamber programmed for a constant temperature of $22^{\circ} \pm 2^{\circ} \mathrm{C}$. The chamber was kept on a cycle of 14 hours of light followed by 10 hours of darkness. New foliage was provided as needed. 
Cage design. All laboratory studies were conducted with self-watering acrylic plastic cages as designed by Munger and Gilmore (1963) and modified by Tashiro (1967). These cages were capable of maintaining either soybean or pinto bean leaves in good condition for three weeks. A single pair of mites were held in each cage for three to five days and then transferred to a new leaf because too many progeny in a cage depleted the available food supply before the mites matured. Mites were transferred from one cage to another by gently lifting them off of the leaf with a minuten insect pin glued to a small balsa wood stick. Once on the pin, they were allowed to crawl off as the pin was held against the new leaf.

\section{Greenhouse study}

Before initiating large-scale field trials, a pilot study was conducted on a few strawberry plants in a greenhouse (maintained at $24 \pm 5^{\circ} \mathrm{C}$ ) to obtain preliminary information on the usefulness of sterile mites for population suppression. Several factors contributing to the potential success in field control determined during this study included rearing procedures, treatment methods, release procedures, and what was thought to be a favorable ratio of sterile to normal mites for control.

Pinto bean seeds were planted in a $1: 1$ mixture of vermiculite and soil in plastic pans $63 / 4$ inches long by $31 / 4$ inches wide by $21 / 4$ inches deep. Plants 6 to 8 inches high were inoculated with mites by placing several infested leaf trifoliates from the stock colony on the pinto bean foliage. The mites were allowed to reproduce for 12 to 14 days and then irradiated while still on the bean foliage (fig. 1). Four of the plastic pans fit into the irradiation chamber at one time. The pinto bean leaves harboring the sterile mites were then cut from the stems and several leaf trifoliates were placed on the strawberry plants.
As the leaves desiccated, the mites moved off onto the strawberry foliage and mixed with the endemic normal population.

\section{Field studies}

Knipling (1955, 1964) and LaChance, Schmidt, and Bushland (1967) discussed several factors that must be considered before attempting field control of a species by the release of sterile individuals. These include a knowledge of the optimum dose and life stage for sterilization; effects of this dose on mating behavior, competitiveness, and longevity; the type of sterilization induced; the ratio of sterile to normal individuals needed to obtain control; an economical method of rearing, treating, and releasing large numbers of the pest species; and basic information on the reproductive biology and population dynamics of the species. Current losses and control costs should be considered in determining the practicality of using sterile individuals for population control. Lastly, the effects of releasing large numbers of sterile organisms into the environment must not cause undue losses to crops or livestock, or create hazards for man that outweigh the benefits of ultimate control.

After studying each of these aspects in considerable detail, the two-spotted mite appeared to be a likely candidate for control by this method. However, factors that could cause the technique to fail for this species include: (1) parthenogenetic females that produce normal $F_{1}$ males even though mated to a sterile male; (2) the possibility that the release of numbers sufficient to obtain control would result in excessive feeding damage to the plants; (3) the distribution of sterile mites into a field population, which normally assumes a random or negative binomial distribution, so that maximum use of the sterile males is obtained; and (4) the mechanics of releasing large numbers of sterile 


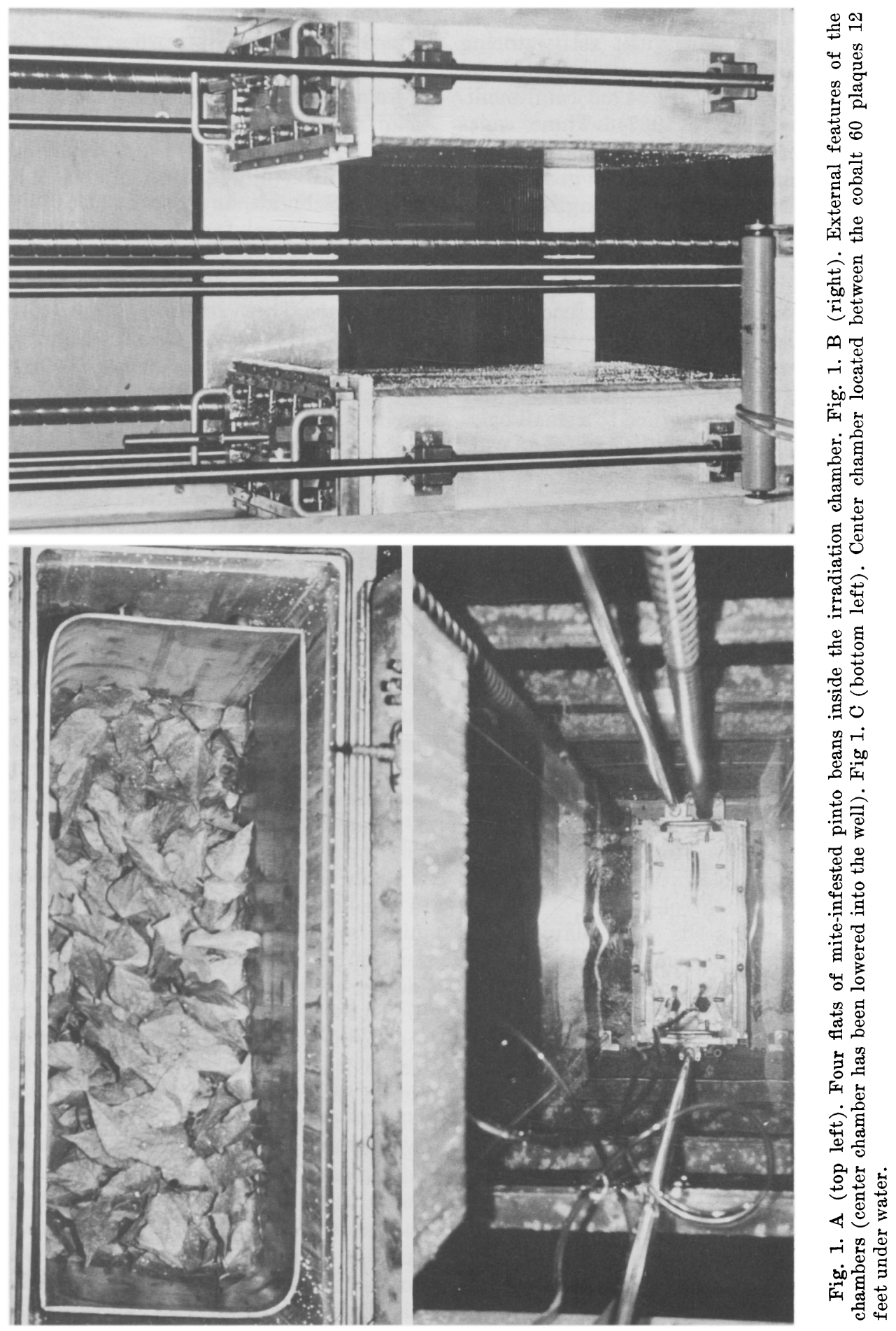


mites into the field. These problems were considered surmountable, and field experiments were initiated. Our primary objective was not eradication, but maintenance of the population below economic levels.

Release of sterile individuals of both sexes. The methods used in rearing, treating, and releasing mites were identical to those described for the greenhouse studies. Mites were reared on pinto beans, irradiated with $25 \mathrm{krads}$, and distributed into the field plot by placing the detached bean leaves on the strawberry plants. From results of the greenhouse test, it was decided that mites of all ages and both sexes would be released at a 9:1 ratio of sterile to normal mites. The spring of 1968 was unusually warm, and a survey of the plot area made just before the releases in March showed an excessively high population of mites for that time of year. One prerequisite for success by this method is to have the natural population density at a low level when sterile individuals are introduced. This is especially important when releasing an active feeding stage onto a crop, as is the case with mites. An attempt to reduce the population to a lower level was made by spraying the plot with a miticide combination of dicofol (Kelthane ${ }^{\circledR}$ ) and endosulfan (Thiodan ${ }^{\circledR}$ ) on March 12, 1968. Both were applied at 2 pounds of active ingredient per acre in 150 gallons of water.

Release of sterile males. Detrimental effects of feeding by an excessive number of mites were illustrated in the first field trial when sterile individuals of both sexes were released. McEnroe (1961) reported that the fluid intake of mites amounts to as much as 20 to 25 per cent of their total volume and weight per hour. Because the total volume and weight of the female is probably twice that of the male, and because the female requires a greater amount of fluid intake for egg production, it is reasonable to suspect that the female extracts at least twice as much fluid from the feeding substrate as does the male. A colony of mites usually has a sex ratio favoring the females (Gasser, 1951). This was also found to be the case under our previously described rearing conditions; therefore, the releases resulted in a sex ratio favoring the females.

The presence of sterile females does not significantly contribute to the ultimate control of a species, according to most workers. If the number of matings by the male and female was the same, or if the female mates more often than the male, then a release of sterile females may be of some consequence. Husseiny and Madsen (1964) report that a release of both sexes was more effective in controlling the navel orangeworm than a release of males or females alone. This phenomenon is certainly of less importance when the male mates more often than the female, which is the usual case for most arthropods. It was found that a single adult male mite fertilized six out of eight virgin females in a 24-hour period with sufficient sperm for their entire lives. Laboratory studies also showed that only 10 to 12 per cent of the females underwent more than one effective mating (i.e., resulting in fertilization). Therefore, a release of only sterile males would cause less feeding damage and should prove to be more effective than a release of both sexes. A second field test was initiated to test this hypothesis.

An all-male population was reared by isolating ten quiescent deutonymph females in each of several acrylic plastic cages. These females were transferred into new cages with a fresh pinto bean leaf every fourth day. Eggs from these females were all haploid, and thus destined to be males. The eggs were allowed to hatch, and the leaf was then removed 
from the cage and placed on top of a flat of pinto bean foliage. As the excised leaf desiccated, the small male mites crawled off onto the fresh bean foliage. These flats were maintained in a growth chamber at $26^{\circ} \pm 1^{\circ} \mathrm{C}$ and 16 hours of daylight. The method of irradiating and releasing the mites was identical to that described for the first field experiment.

\section{LABORATORY STUDIES: RESULTS AND DISCUSSION}

\section{Establishment of a sterilizing dose for males and females}

The work of Henneberry (1964) on gamma irradiation of the two-spotted spider mite served as a basis for further work toward our objective of using gamma radiation for suppression of this mite on strawberries. Some of Henneberry's work was repeated, and additional work was done to determine the effects of gamma radiation on other aspects of the biology of the mite. Henneberry reported that untreated female two-spotted mites mated with males exposed to 8, 16, or 24 krads produced fewer females and more nonviable eggs than did females of untreated pairs. These effects were dosage-dependent. Females mated to males exposed to 32 krads produced only nonviable eggs. Treated females mated to normal males produced fewer females and males, and these reductions were dosage-dependent. Females treated with 32 krads produced only nonviable eggs.

An interesting comparison with Henneberry's results are those of Beavers et al. (1971) who found that male and female citrus red mites, Panonychas citri (McGregor), were sterilized at doses of 24 and $32 \mathrm{krads}$, respectively.

Adult male mites were selected at random from the stock colony and placed on an excised soybean leaf in an acrylic plastic cage. They were then irradiated at various dosages from 10 to $60 \mathrm{krads}$ at 10 -krad increments. After treatment, a single normal quiescent deutonymph female was placed in each cage. Each pair was transferred to a new cage with fresh foliage every three to five days, and tests were continued until the female died naturally. The following parameters were measured: total number of eggs, number of nonviable eggs, number of viable eggs, sex ratio of the $F_{1}$ generation, and longevity of the female (table 1).

A dose of 10 krads caused about 50 per cent of the eggs to be nonviable. Of those eggs that hatched, about 32 per cent were females. At $20 \mathrm{krads}, 64 \mathrm{per}$ cent of the eggs were nonviable. Those that hatched were almost exclusively males. Complete sterilization of the male occurred at 30 krads and above, as indicated by the all-male $F_{1}$ progeny.

Adult female mites were also selected at random, placed in cages, and treated at 10 to $60 \mathrm{krads}$ at 10 -krad increments, after which a single untreated adult male was introduced into each cage. The remaining manipulations were identical to those described above. At $10 \mathrm{krads}, 53$ per cent of the eggs were nonviable (table 2). All male progeny resulted from the female of the first replicate $(10 \mathrm{krads})$. This is probably due to the female's never mating and not to the effects of radiation. All females in this test were rendered sterile by 20 to $60 \mathrm{krads}$, and only a few eggs were laid by each female after irradiation. As the females were gravid at the time of treatment, it is presumed that some well-developed eggs were in their oviducts. After these were expelled, females became infecund due to destruction of the germ tissue.

\section{Effect of a 20-krad dose on subsequent $\mathrm{F}_{1}$ progeny}

A randomly selected group of $F_{1}$ females, from matings where the paren- 
TABLE 1

STERILIZING EFFECTS OF 10, 20, 30, 40, 50, OR 60 KRADS ON ADULT MALE TWO-SPOTTED MITES SUBSEQUENTLY MATED WITH VIRGIN ADULT FEMALES

\begin{tabular}{|c|c|c|c|c|c|c|c|}
\hline \multirow{2}{*}{ Dose } & \multirow{2}{*}{$\begin{array}{l}\text { Replicate } \\
\text { Number }\end{array}$} & \multicolumn{3}{|c|}{ Eggs produced } & \multicolumn{2}{|c|}{ Sex of $F_{1}$} & \multirow{2}{*}{$\begin{array}{l}\text { Longevity } \\
\text { of femsle }\end{array}$} \\
\hline & & \multirow{2}{*}{$\frac{\text { Total }}{\text { Number }}$} & \multicolumn{2}{|c|}{ Nonviable } & Male & Female & \\
\hline \multirow{3}{*}{$\begin{array}{c}\text { Krads } \\
10 \ldots \ldots \ldots \ldots\end{array}$} & & & Number & Per cent & & & Days \\
\hline & 1 & 133 & 81 & 60.9 & 68.7 & 31.3 & 34 \\
\hline & 2 & 128 & 52 & 40.6 & 65.8 & 34.2 & 23 \\
\hline \multirow[t]{2}{*}{$20 \ldots \ldots \ldots \ldots \ldots$} & 1 & 208 & 134 & 64.4 & 100.0 & 0.0 & 34 \\
\hline & 2 & 78 & 50 & 64.1 & 89.3 & 10.7 & 27 \\
\hline \multirow[t]{2}{*}{$30 \ldots \ldots \ldots \ldots \ldots$} & 1 & 18 & 11 & 61.1 & 100.0 & 0.0 & 8 \\
\hline & 2 & 68 & 55 & 80.9 & 100.0 & 0.0 & 15 \\
\hline \multirow[t]{2}{*}{$40 \ldots \ldots \ldots \ldots \ldots$} & 1 & 110 & 82 & 74.5 & 100.0 & 0.0 & 19 \\
\hline & 2 & 46 & 20 & 43.4 & 100.0 & 0.0 & 15 \\
\hline \multirow[t]{2}{*}{$50 \ldots \ldots \ldots \ldots \ldots$} & 1 & 160 & 93 & 58.1 & 100.0 & 0.0 & 19 \\
\hline & 2 & 63 & 47 & 74.6 & 100.0 & 0.0 & 15 \\
\hline \multirow[t]{2}{*}{$60 \ldots \ldots \ldots \ldots \ldots$} & 1 & 101 & 13 & 12.9 & 100.0 & 0.0 & 22 \\
\hline & 2 & 102 & 21 & 20.6 & 100.0 & 0.0 & 26 \\
\hline \multicolumn{8}{|l|}{ Check: } \\
\hline $0 \ldots \ldots$ & 1 & 179 & 3 & 1.7 & 61.4 & 38.6 & 34 \\
\hline $0 \ldots \ldots \ldots \ldots \ldots$ & 2 & 109 & 8 & 7.3 & 24.7 & 75.3 & 23 \\
\hline $0 \ldots \ldots \ldots \ldots \ldots$ & 3 & 135 & 5 & 3.7 & 86.1 & 13.9 & 23 \\
\hline
\end{tabular}

tal male was not rendered completely sterile (e.g., at $20 \mathrm{krads}$ ), were mated to normal males and the $F_{2}$ eggs scored for per cent viability. Eight $\mathrm{F}_{1}$ females were included in the first test. Three females laid no eggs at all; the other five laid a reduced number of eggs which were all nonviable (table 3 ). This phenomenon would be an asset in the control of field populations, for death of the $F_{1}$ progeny would not be a requisite for eventual population suppression. In subsequent tests an occasional female treated with $20 \mathrm{krads}$ was found to produce living offspring. Therefore, the reciprocal to the first experiment

TABLE 2

STERILIZING EFFECT OF 10, 20, 30, 40, 50, OR 60 KRADS ON ADULT FEMALE TWO-SPOTTED MITES SUBSEQUENTLY MATED WITH ADULT MALES

\begin{tabular}{|c|c|c|c|c|c|c|c|}
\hline \multirow{2}{*}{ Dose } & \multirow{2}{*}{$\begin{array}{l}\text { Replicate } \\
\text { number }\end{array}$} & \multicolumn{3}{|c|}{ Eggs produced } & \multicolumn{2}{|c|}{ Sex of $F_{1}$} & \multirow{2}{*}{$\begin{array}{l}\text { Longevity } \\
\text { of female }\end{array}$} \\
\hline & & Total & \multicolumn{2}{|c|}{ Nonviable } & Male & Female & \\
\hline \multirow{3}{*}{$\begin{array}{r}\text { Krads } \\
10 \ldots \ldots \ldots \ldots\end{array}$} & & Number & Number & Per cent & & & Days \\
\hline & 1 & 67 & 34 & 50.7 & 100.0 & 0.0 & 34 \\
\hline & 2 & 99 & 54 & 54.5 & 55.5 & 44.5 & 23 \\
\hline \multirow[t]{2}{*}{20.} & 1 & 18 & 18 & 100.0 & $\cdots$ & $\cdots$ & 8 \\
\hline & 2 & 31 & 31 & 100.0 & $\ldots$ & $\ldots$ & 22 \\
\hline \multirow[t]{2}{*}{$30 \ldots$} & 1 & 14 & 14 & 100.0 & $\cdots$ & $\cdots$ & 15 \\
\hline & 2 & 28 & 28 & 100.0 & $\cdots$ & $\ldots$ & $6^{*}$ \\
\hline \multirow[t]{2}{*}{$40 \ldots \ldots \ldots \ldots \ldots$} & 1 & 21 & 21 & 100.0 & $\ldots$ & $\ldots$ & 21 \\
\hline & 2 & 18 & 18 & 100.0 & $\ldots$ & $\ldots$ & 5 \\
\hline \multirow[t]{2}{*}{$50 \ldots \ldots \ldots \ldots \ldots$} & 1 & 0 & $\ldots$ & $\ldots \ldots$ & $\cdots$ & $\ldots$ & 21 \\
\hline & 2 & 33 & 33 & 100.0 & $\ldots$ & $\ldots$ & 21 \\
\hline \multirow[t]{2}{*}{$60 \ldots \ldots \ldots \ldots \ldots$} & 1 & 35 & 35 & 100.0 & $\ldots$ & $\cdots$ & 21 \\
\hline & 2 & 13 & 13 & 100.0 & $\cdots$ & $\ldots$ & 5 \\
\hline \multicolumn{8}{|l|}{ Check: } \\
\hline $0 \ldots \ldots \ldots \ldots \ldots$ & 1 & 179 & 3 & 1.7 & 61.4 & 38.6 & 34 \\
\hline $0 \ldots \ldots \ldots \ldots \ldots$ & 2 & 109 & 8 & 7.3 & 24.7 & 75.3 & 23 \\
\hline $0 \ldots \ldots \ldots \ldots \ldots$ & 3 & 135 & 5 & 3.7 & 86.1 & 13.9 & 23 \\
\hline
\end{tabular}

- Killed accidentally. 
TABLE 3

EFFECTS ON $F_{2}$ TWO-SPOTTED SPIDER MITES FROM A SUBSTERILIZING DOSE ON $P_{1}$ MITES

\begin{tabular}{|c|c|c|c|c|c|c|c|}
\hline \multirow{3}{*}{$\begin{array}{c}\text { Female } \\
\text { no. }\end{array}$} & \multicolumn{3}{|c|}{ Eggs produced } & \multicolumn{2}{|c|}{ Sex of $F_{2}$} & \multicolumn{2}{|c|}{ Longevity of $F_{1}$} \\
\hline & Total & & ble & Male & Female & Male & Female \\
\hline & Number & Number & Per cent & \multicolumn{2}{|c|}{ Per cent } & \multicolumn{2}{|c|}{ Days } \\
\hline
\end{tabular}

Progeny of $F_{1}$ female caged with normal male*

\begin{tabular}{|c|c|c|c|c|c|c|c|}
\hline $1 \ldots \ldots \ldots \ldots$ & 0 & $\ldots$ & . & . & $\ldots$ & $\ldots$ & 30 \\
\hline $2 \ldots \ldots \ldots \ldots$ & 47 & 47 & 100 & . & . & . & 12 \\
\hline $3 \ldots \ldots \ldots \ldots$ & 68 & 68 & 100 & . & . & . & 32 \\
\hline $4 \ldots \ldots \ldots \ldots$ & 19 & 19 & 100 & . & .. & .. & 20 \\
\hline $5 \ldots \ldots \ldots \ldots$ & 0 & 0 & . & . & $\ldots$ & . & 20 \\
\hline $6 \ldots \ldots \ldots \ldots$ & 21 & 21 & 100 & . & . & . & 9 \\
\hline $7 \ldots \ldots \ldots \ldots$ & 20 & 20 & 100 & . & . & .. & 9 \\
\hline $8 \ldots \ldots \ldots \ldots$ & 0 & 0 & . & . & $\ldots$ & . & 9 \\
\hline
\end{tabular}

Progeny of $F_{1}$ adult male caged with normal virgin female $\dagger$

\begin{tabular}{|c|c|c|c|c|c|c|c|}
\hline $1 \ldots \ldots \ldots \ldots$ & 135 & 7 & 5.2 & 100.0 & 0.0 & 9 & 30 \\
\hline 2. & 155 & 1 & 0.6 & 48.7 & 51.3 & 9 & 26 \\
\hline $3 \ldots$ & 109 & 63 & $\mathbf{5 7 . 8}$ & 95.7 & 4.3 & 35 & 26 \\
\hline $4 \ldots \ldots \ldots \ldots$ & 203 & 29 & 14.3 & 38.5 & 61.5 & 27 & 42 \\
\hline $5 \ldots \ldots \ldots \ldots$ & 185 & 8 & 4.3 & 41.8 & 58.2 & 27 & 42 \\
\hline $6 \ldots \ldots \ldots \ldots$ & 43 & 0 & 0.0 & 33.3 & 66.7 & $10 \ddagger$ & $10 \ddagger$ \\
\hline
\end{tabular}

* Female was progeny of $P_{1}$ male irradiated with $20 \mathrm{krads}$ and mated with an untreated virgin female.

$\dagger$ Male was progeny of virgin female irradiated with $20 \mathrm{krads}$ and mated with an untreated male.

$\$$ Accidentally killed.

was also conducted; that is, $\mathrm{F}_{1}$ males from parental females that had received a 20-krad dose were mated to normal virgin females and the resulting nonviable $\mathrm{F}_{2}$ eggs were counted. The second experiment consisted of six replicates where $F_{1}$ males from treated $P_{1}$ females were mated to virgin females. Four of these females exhibited normal egg production, egg viability, longevity, and sex ratio in the $\mathrm{F}_{2}$ progeny, indicating no apparent effect in the male progeny from substerilized females (table 3 , second part). One exception had 58 per cent nonviable eggs, and 96 per cent of those eggs that hatched were males. Another female with 14 per cent nonviable eggs, but a normal $\mathrm{F}_{1}$ sexratio, was not considered abnormal. In light of these results, greenhouse and field tests were conducted using 25 krads as a sterilizing dose.

\section{LD50/10 values for males and females}

The LD50/10 is defined as the maximum dose that will kill 50 per cent of the mites within ten days. This value is strictly of an academic nature as the important question in a successful control program by the sterile-male technique is whether the sterilizing dose influences longevity in a detrimental fashion. The most efficient use of a sterile male released into a field population results from one which has a normal life span. Data concerning this subject are presented in the section dealing with the effects of radiation on various ages of males.

To determine the LD50/10 value for males, ten three-day-old adults were placed in separate cages on bean foliage and exposed to doses ranging from 90 to 
110 krads. The longevity curve for untreated adults was determined with 25 individuals. Fifteen to 25 three-day-old virgin-adult females were exposed to doses ranging from 60 to 130 krads. Figures 2 and 3 show results from both experiments. They indicate that females have an LD 50/10 of between 100 and $120 \mathrm{krads}$, while that of males is about 90 krads. The LD 100/10 (the minimum dose which kills 100 per cent of the individuals within 10 days) is about 130 krads for females and about 95 krads for males. The males also seem to be more susceptible in their general reaction to radiation as well. Five days after exposure to $100 \mathrm{krads}$ all males were about one-half their normal size, appeared pale and dehydrated, and waved their legs in seemingly uncontrollable spasms. Females do not attain this shriveled appearance until exposed to at least 120 to $130 \mathrm{krads}$, although they do become very pale and lose their characteristic lateral spots from a sterilizing dose of 25 krads.

Cagle (1949) reports the average life span for 210 adult females from 11 generations was 22 days, while that for 88 adult males from 16 generations was 28 days. The present data confirm his findings (assuming normal biologic variation).

\section{Radiosensitivity of eggs at various ages}

Rapidly dividing cells are more susceptible to radiation than is tissue comprised of nondividing cells. Thus, one should observe an increased degree of resistance to radiation as the embryo matures. The egg stage for this species is approximately four days at $22^{\circ} \mathrm{C}$.

Three gravid females were selected at random from the stock colony and placed on a bean leaf in each of several plastic cages for 24 hours, after which the mites were destroyed. The eggs laid during this time were counted and held until the desired age had been attained.
Four age groups were used: 1 to 24,25 to 48,49 to 72 , and 73 to 96 hours. Each dose was replicated three times, with each replicate having an average of 30 eggs. Eggs were exposed to doses ranging from 1,200 to 14,500 rads. Exposures up to 8,500 rads were made at the 30 -inch position in the well. All other tests $(8,500$ to $14,500 \mathrm{rads})$ were conducted with the irradiation chamber lowered to the bottom of the well, so that the source plaques were on either side of the chamber. In this position, a reproducible low dose is difficult to attain, because exposure time would be only a few seconds. Therefore, the chamber was held 30 inches above the bottom of the well for the low dosages. In this position, the bottom of the chamber is situated just above the top of the source plaque. Fricke dosimetry measurements were made at this position before this series of experiments were started. During the tests, cages were placed on the bottom of the chamber rather than on the rack which was used during all other experiments. Table 4 shows results of these experiments.

The results indicate that one- and twoday-old eggs had a similar dose-effect response with an LD50 value of 2,100 to 2,300 rads and an LD100 value of 3,000 to 3,200 rads. According to Hewitt (1963), the blastoderm is completely formed in the 6-hour embryo of the twospotted mite. First evidence of segmentation occurs in the 19-to-20-hour embryo when cheliceral and pedipalpal segments form from the anterior polar caps and the leg buds form as two clumps of cells from the germ band. The period of rapid cell proliferation therefore probably occurs in the first 48 hours of embryonic life-this is the period when one would expect the embryo to be most radiosensitive (which, in fact, it was). The three-day-old eggs appeared to have an LD50 of about 4,000 rads and an LD100 in excess of 8,500 rads. No significant mortality was in- 


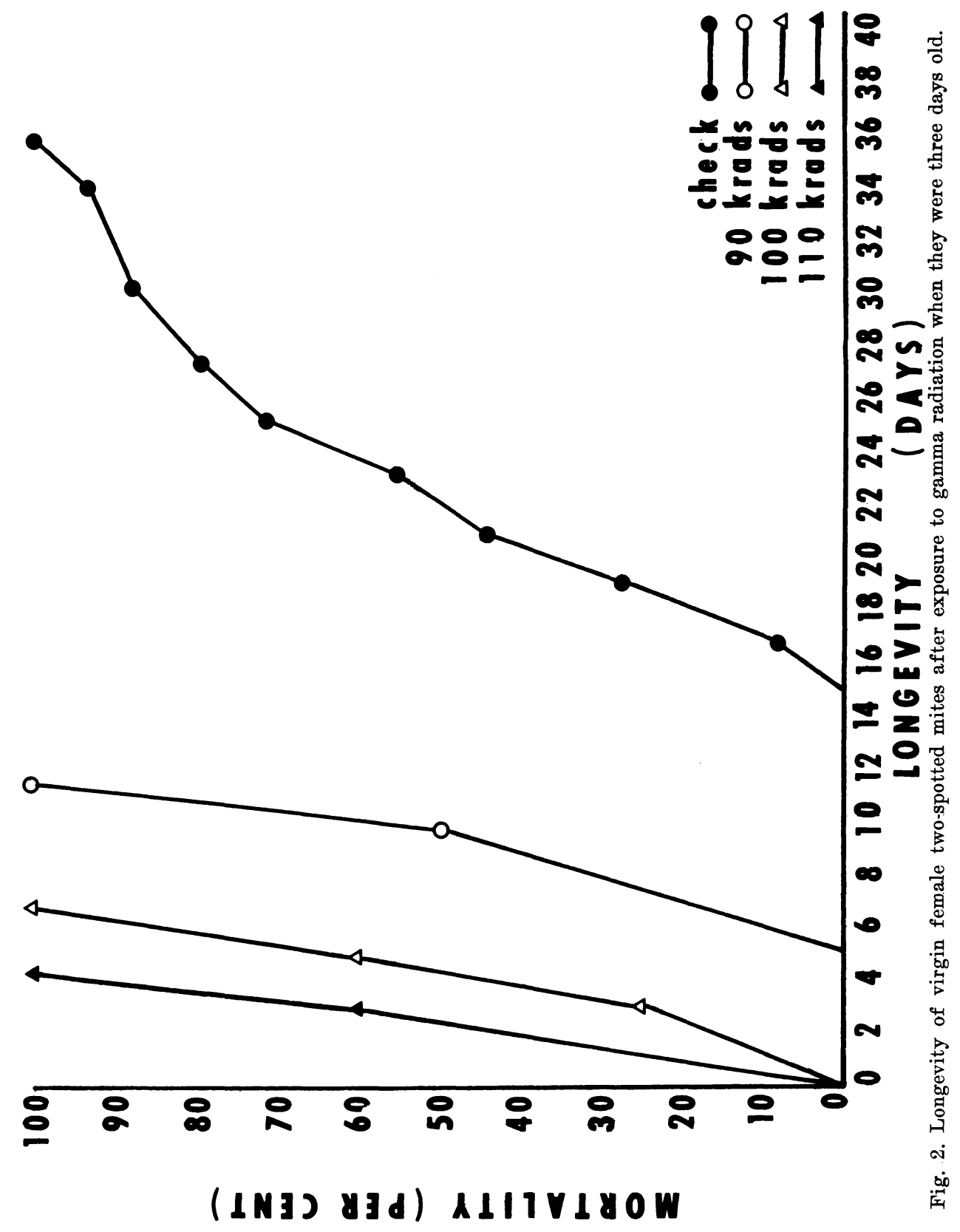




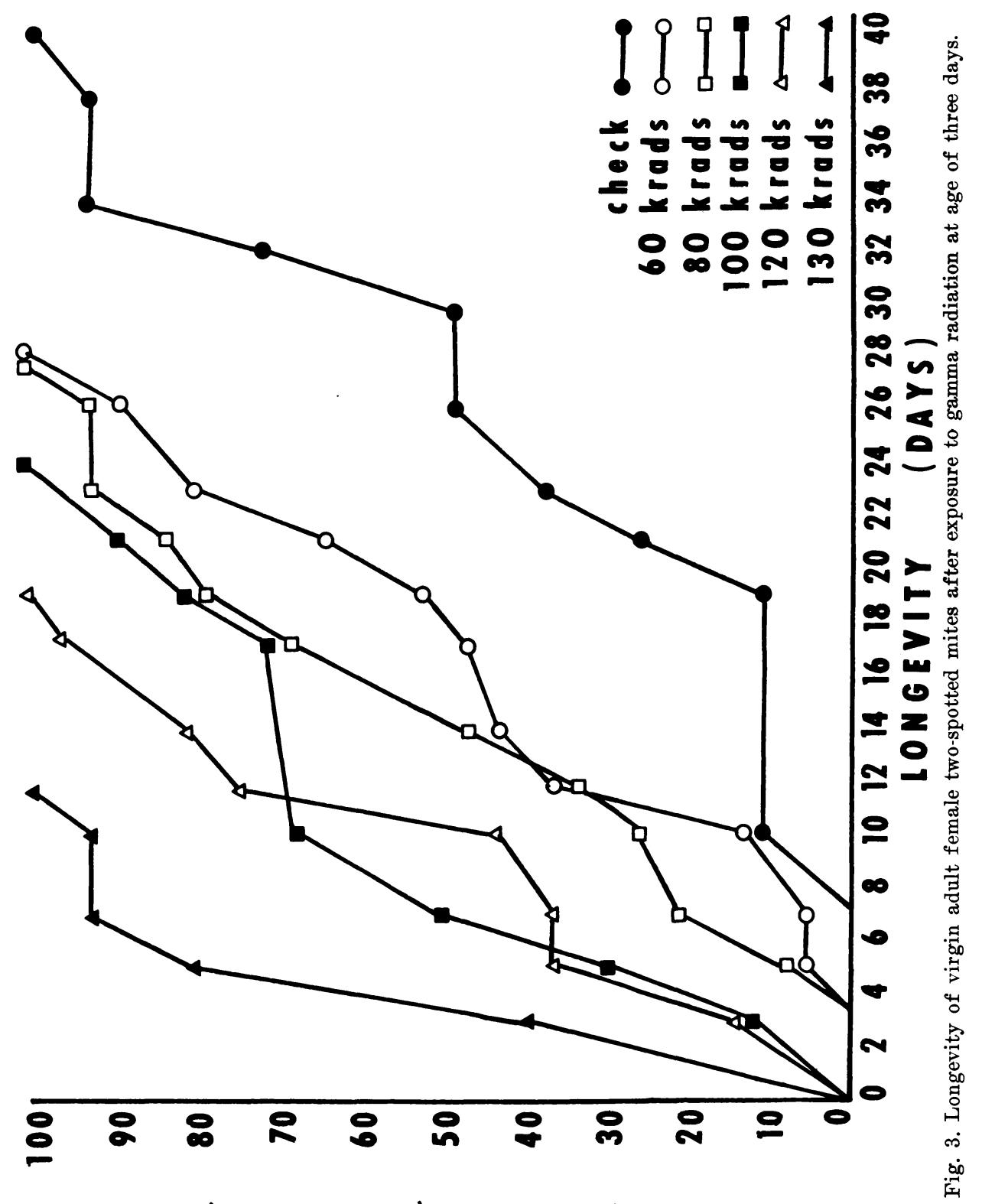

(IN3) y3d) ALITI8OW 
TABLE 4

RADIOSENSITIVITY OF TWO-SPOTTED MITE EGGS OF VARIOUS AGES AS DETERMINED AT TWO POSITIONS IN THE COBALT-60 WELL

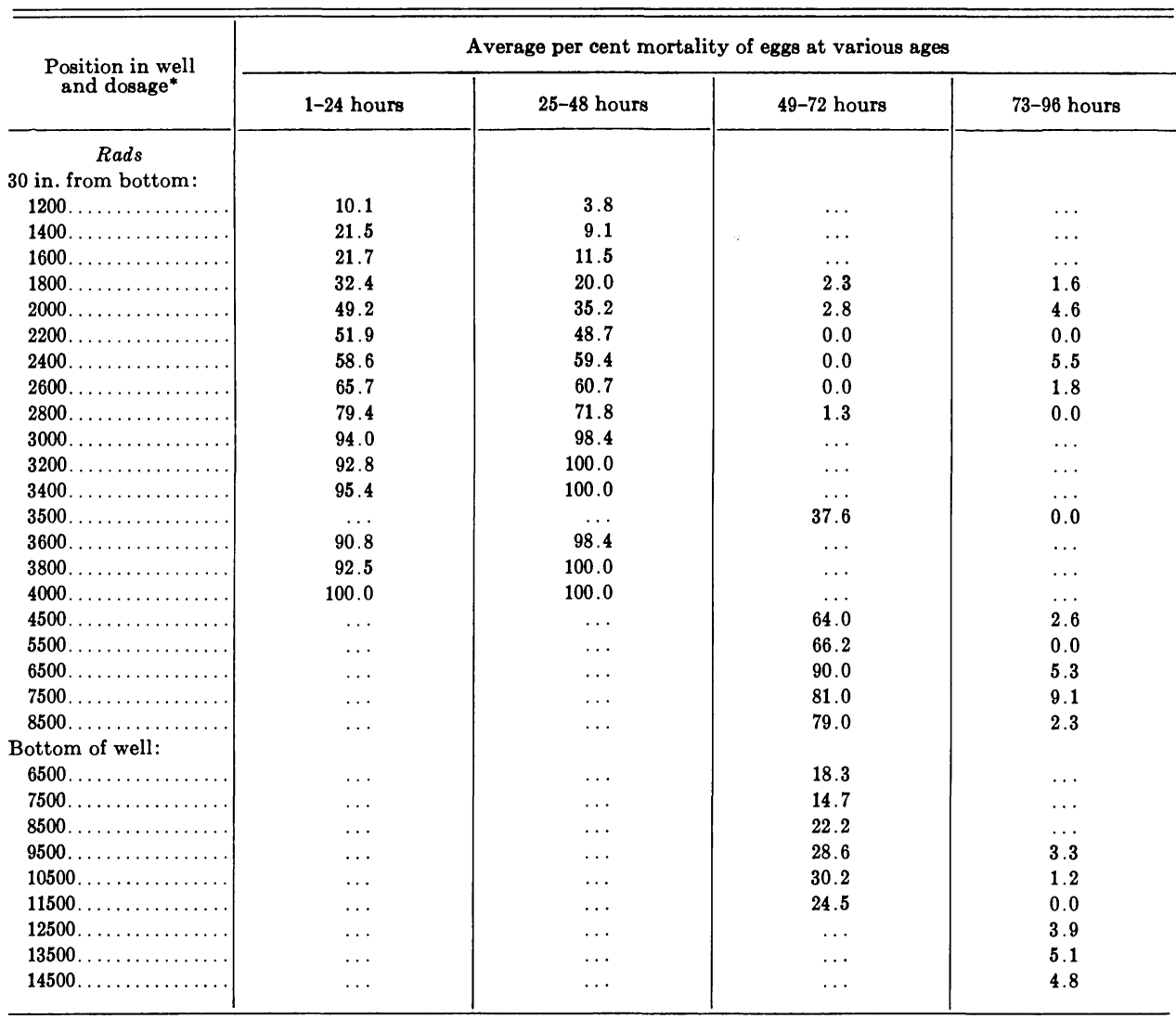

- Each dosage was tested on three replicates with an average of 30 eggs per replicate.

duced in four-day-old eggs below 8,500 rads at the 30 -inch position. Burkholder, Tilton, and Cogburn (1966) found that 18 per cent of 11-day-old eggs of the grain mite, Acarus siro L., hatched after being exposed to 100 krads. Eleven-day-old eggs irradiated with 13.2 krads were hardly affected in this species.

The apparent discrepancy between the same dose at different positions in the well should be noted. At the 30 -inch position 8,500 rads killed 79 per cent of the eggs, while the same dose killed only 22 per cent of the eggs when the chamber was lowered between the source plaques to the bottom of the well. At the lower position, 12,500 rads resulted in only 25 per cent egg mortality in threeday-old eggs and 14,500 rads gave only a 5 per cent egg mortality in four-dayold eggs. Effects of radiation on various ages of males showed that $20 \mathrm{krads}$ (chamber at the bottom of the well) killed all three- and four-day-old eggs. This demonstrates the importance of carefully stating the position of the biological material in relation to the source. At the 30-inch position, the photons must travel through a certain amount of water before coming in contact with the subject material. Thus, their veloc- 
TABLE 5

INCIDENCE OF NONVIABLE EGGS FROM ADULT TWO-SPOTTED MITES IRRADIATED DURING THE EGG STAGE*

\begin{tabular}{|c|c|c|c|c|c|}
\hline \multirow{2}{*}{$\begin{array}{l}\text { Dose } \\
\text { (Rads) }\end{array}$} & \multirow{2}{*}{ Cross $\dagger$} & \multicolumn{4}{|c|}{$\begin{array}{l}\text { Per cent nonviability in } F_{1} \text { eggs when parental } \\
\text { egg was irradiated at age of: }\end{array}$} \\
\hline & & 1-24 hours & 25-48 hours & 49-72 hours & 43-96 hours \\
\hline \multirow[t]{2}{*}{$1800 \ldots \ldots \ldots$} & $T(M) X N(F)$ & 4.0 & 0.0 & 1.1 & $\ldots$ \\
\hline & $N(M) X T(F)$ & $\ldots$ & 3.3 & $\ldots$ & $\ldots$ \\
\hline \multirow[t]{2}{*}{2000 . } & $T(M) \times N(F)$ & $\ldots$ & $\ldots$ & 1.7 & $\ldots$ \\
\hline & $N(M) X T(F)$ & $\ldots$ & $\ldots$ & 16.7 & $\cdots$ \\
\hline \multirow[t]{2}{*}{2200 . . } & $T(M) \times N(F)$ & $\ldots$ & $\ldots$ & 3.9 & 2.9 \\
\hline & $N(M) X T(F)$ & $\ldots$ & $\ldots$ & 34.8 & 8.9 \\
\hline \multirow[t]{2}{*}{2400 . } & $T(M) \times N(F)$ & 2.5 & 2.2 & $\cdots$ & 0.0 \\
\hline & - $\quad \mathrm{N}(\mathrm{M}) \times \mathrm{T}(\mathrm{F})$ & 3.2 & 36.7 & 16.5 & 19.1 \\
\hline \multirow[t]{2}{*}{2600 . } & $\mathrm{T}(\mathrm{M}) \mathrm{X} \mathrm{N}(\mathrm{F})$ & $\cdots$ & $\ldots$ & 1.9 & $\ldots$ \\
\hline & $N(M) X T(F)$ & $\ldots$ & $\ldots$ & 29.4 & $\ldots$ \\
\hline \multirow[t]{2}{*}{2800 . } & $T(M) \times N(F)$ & 3.2 & $\cdots$ & 1.0 & 4.5 \\
\hline & $N(M) X T(F)$ & 3.0 & 38.5 & 17.3 & 13.9 \\
\hline
\end{tabular}

* Eggs of various ages were treated and each hatched and matured mite was caged with a normal individual of the opposite sex.

$\dagger \mathrm{T}=$ treated; $\mathrm{N}=$ normal; $\mathrm{M}=$ male; $\mathrm{F}=$ female. Each cross represents 8 to 12 individual pairs.

ity is decreased and this in effect decreases the linear energy transfer (LET) and increases the relative biological effectiveness (RBE). A rad of gamma rays at the zero-inch position is not equal to what is being termed a rad at the 30-inch position due to the change in the type of radiation. If one knew how much of each type of radiation was present (and its respective LET) at the 30 -inch position, the actual amount of energy deposited per gram of absorber could be calculated to give an absolute value. This phenomenon may account for the greater egg mortality at the 30 -inch position as opposed to the zero-inch position.

To determine whether individuals surviving irradiation in the egg stage would be sexually sterile as adults, both sexes (treated as eggs) were caged separately with normal mites of the opposite sex. These paired matings were not observed throughout the entire life of the mites, but only long enough to ascertain the incidence of sterility that may be induced from exposing the egg stage to gamma rays. Four ages of haploid eggs exposed to doses of 1,800 to
2,800 rads did not induce sterility in the resultant males. Females from treated eggs, however, laid up to 38 per cent nonviable eggs except for females irradiated as 1-to-24-hour-old eggs where no effect was observed (table 5). Higher doses administered to three- and four-day-old eggs may result in sterility at adulthood.

\section{Effect of age on radiosensitivity of males}

If the dose that sterilizes adults also induced sterility in younger stages, one could irradiate several age classes, release them into a field population, and be assured of some sexually mature sterile males being added to the reproductive force over a period of days. Therefore, three- and four-day-old eggs, larvae, protonymphs, deutonymphs, newly emerged adults, and two- and three-day-old adults were irradiated with 20 krads. The surviving stages were caged with a quiescent deutonymph female as they became sexually mature, and the degree of sterility, $\mathrm{F}_{1}$ sex ratio, and longevity of males and females were recorded (table 6). 
TABLE 6

VIABILITY OF F 1 EGGS FROM VIRGIN FEMALE TWO-SPOTTED MITES PAIRED WITH MALES EXPOSED TO 20 KRADS AT VARIOUS LIFE STAGES

\begin{tabular}{|c|c|c|c|c|c|c|c|c|}
\hline \multirow{2}{*}{$\begin{array}{l}\text { Stage of male } \\
\text { when irradiated }\end{array}$} & \multirow{2}{*}{$\begin{array}{l}\text { Replicate } \\
\text { number }\end{array}$} & \multicolumn{3}{|c|}{ Eggs produced } & \multicolumn{2}{|c|}{ Sex of $F_{1}$} & \multicolumn{2}{|c|}{$\begin{array}{l}\text { Longevity } \\
\text { of } P_{1} \text { adults }\end{array}$} \\
\hline & & Total & \multicolumn{2}{|c|}{ Nonviable } & Male & Female & Males & Females \\
\hline & & Number & Number & Per cent & & & & \\
\hline \multicolumn{9}{|l|}{ Eggs and larvae* } \\
\hline Protonymph.... & 1 & 197 & 86 & 43.7 & 100.0 & 0.0 & 22 & 37 \\
\hline Protonymph.... & 2 & 170 & 67 & 39.4 & 100.0 & 0.0 & 28 & 28 \\
\hline Protonymph.... & 3 & 232 & 43 & 18.5 & 100.0 & 0.0 & 22 & 37 \\
\hline Protonymph.... & 4 & 168 & 48 & 28.6 & 100.0 & 0.0 & 15 & 30 \\
\hline Deutonymph........ & 1 & 164 & 104 & 63.4 & 90.0 & 10.0 & 22 & 22 \\
\hline Deutonymph........ & 2 & 162 & 133 & 82.1 & 62.1 & 37.9 & 9 & 26 \\
\hline Deutonymph........ & 3 & 49 & 39 & 79.6 & 100.0 & 0.0 & 9 & 15 \\
\hline Deutonymph..... & 4 & 46 & 42 & 91.3 & 50.0 & 50.0 & . & . \\
\hline \multicolumn{9}{|l|}{ Adult: } \\
\hline Newly emerged...... & 1 & 137 & 98 & 71.5 & 89.7 & 10.3 & 22 & 37 \\
\hline Newly emerged.. & 2 & 137 & 90 & 65.7 & 78.3 & 21.7 & 9 & 37 \\
\hline Newly emerged. & 3 & 180 & 104 & 57.8 & 88.2 & 11.8 & 22 & 26 \\
\hline Newly emerged. . & 4 & 22 & 17 & 77.3 & 100.0 & 0.0 & 22 & 15 \\
\hline Two days old... & 1 & 147 & 110 & 74.8 & 83.8 & 16.2 & 35 & 31 \\
\hline Two days old . . . . . . & 2 & 75 & 58 & 77.3 & 100.0 & 0.0 & 9 & 22 \\
\hline Two days old ... & 3 & 179 & 141 & 78.8 & 92.1 & 7.9 & 9 & 31 \\
\hline Two days old... & 4 & 214 & 135 & 63.1 & 87.4 & 12.6 & 37 & 37 \\
\hline Three days old... & 1 & 50 & 18 & 36.0 & 100.0 & 0.0 & $?$ & 15 \\
\hline Three days old... & 2 & 119 & 64 & 53.0 & 92.5 & 7.5 & 15 & 26 \\
\hline Three days old... & 3 & 152 & 77 & 70.0 & 91.8 & 8.2 & 15 & 30 \\
\hline Three days old..... & 4 & 198 & 121 & 61.1 & 93.5 & 6.5 & 22 & 33 \\
\hline
\end{tabular}

* Eggs: All three-day-old embryos died before hatching; most four-day-old embryos died before hatching (those that hatched were dead within 24 hours). All larvae died within three days after irradiation.

Eggs and larvae were all killed by 20 krads, while protonymphs, deutonymphs, newly emerged adults, and two- and three-day-old adults exhibited nearly 100 per cent sterility when mated to virgin females. The few $F_{1}$ female progeny resulting from these matings were subsequently found to be sterile. The per cent of nonviable eggs from females mated to males exposed as protonymphs was considerably lower than the per cent observed when treated males of other ages were tested, although the average number of eggs per female was equal to the number expected from untreated mites. Yet, not one $\mathrm{F}_{1}$ female resulted from these matings. It may be that 20 krads administered to a protonymph causes some of the spermatogonial stages to be permanently damaged, so that the individual can only inseminate a female with a portion of the amount of active sperm she would receive from a normal male. Thus, the ratio of male eggs laid would be greater than normal.

\section{Incidence of sperm inactivation in males}

Henneberry (1964) observed that when males were irradiated with 80 to $128 \mathrm{krads}$ and mated to normal females, there was an increase in the number of $\mathrm{F}_{1}$ males and a corresponding decrease in the number of nonviable eggs. To confirm what thus appeared to be sperm inactivation, males were exposed to $60,80,90,100$ or $110 \mathrm{krads}$ and mated with virgin females. Nearly all the females laid from 45 to 65 per cent nonviable eggs, which is within the expected range for females mated to a male exposed to a sterilizing dose of 25 krads (table 7). The three exceptions 
TABLE 7

INCIDENCE OF SPERM INACTIVATION AS INDICATED BY EGG VIABILITY OF NORMAL FEMALE TWO-SPOTTED MITES MATED WITH ADULT MALES EXPOSED TO 60 TO 110 KRADS

\begin{tabular}{|c|c|c|c|c|}
\hline \multirow{3}{*}{$\begin{array}{l}\text { Dose } \\
\text { Krads }\end{array}$} & \multirow{2}{*}{$\begin{array}{l}\text { Replicate } \\
\text { number }\end{array}$} & \multicolumn{3}{|c|}{ Eggs produced } \\
\hline & & \multirow{2}{*}{$\frac{\text { Total }}{\text { Number }}$} & \multicolumn{2}{|c|}{ Nonviability } \\
\hline & & & Number & Per cent \\
\hline $60 \ldots \ldots$ & 1 & 165 & 82 & 49.4 \\
\hline $60 \ldots \ldots$ & 2 & 98 & 6 & $6.1^{*}$ \\
\hline $80 \ldots \ldots$ & 1 & 80 & 21 & 26.3 \\
\hline $80 \ldots$ & 2 & 161 & 94 & 58.4 \\
\hline $90 \ldots \ldots$ & 1 & 71 & 51 & 64.6 \\
\hline $90 \ldots \ldots$ & 2 & 64 & 37 & 57.8 \\
\hline $100 \ldots$ & 1 & 165 & 88 & 53.3 \\
\hline $100 \ldots$ & 2 & 121 & 55 & 45.5 \\
\hline $110 \ldots \ldots$ & 1 & 120 & 1 & $0.8^{*}$ \\
\hline $110 \ldots \ldots$ & 2 & 189 & 2 & $1.1^{*}$ \\
\hline Check... . & 1 & 202 & 18 & 8.9 \\
\hline Check.... & 2 & 117 & 2 & 1.7 \\
\hline
\end{tabular}

* Males in these cages were found dead when examined three days after their introduction, so it is unlikely that any of them had opportunity to mate with the females.

were both replicates at $110 \mathrm{krads}$, and the second replicate at $60 \mathrm{krads}$. In each case the parental male was found dead when examined three days after their introduction. Additionally, all $\mathrm{F}_{1}$ progeny were males-indicating that these females never mated. As mentioned earlier, males exposed to $110 \mathrm{krads}$ would not be expected to live more than five days and are probably in such a debilitated state prior to death that they would be unable to mate. Because so few replicates were included per dose, a definite conclusion cannot be made concerning this contradiction of Henneberry's data.

\section{Incidence of multiple matings by males and females}

Secondary matings by gravid females have been observed, but the incidence and importance of this phenomenon remains questionable. Helle (1967) suggests that the amount of sperm from the first mating determines the success or lack thereof in later mat- ings. His work indicated that the initial mating is not a barrier to subsequent matings, but is rather a barrier to fertilization by sperm of secondary matings. Smith, Boswell, and Henneberry (1965) exposed 100 females to 20 males (10 cages with 10 females and two males per cage) to observe the number of matings per male. One of the males in each cage had been treated with 1 per cent apholate (a chemosterilant), while the other male was a normal untreated individual. Of the 100 females, 13 were unmated, 50 mated with untreated males, 22 mated with treated males, and 14 mated with both the treated and untreated males.

Experiments were designed to gain further information concerning the reproductive biology of the mite. A male sterilized with 25 krads was caged with a virgin female and replaced with a normal male one week later. If, in fact, the female mates more than once, and the sperm from the normal male are competitive with the first, normal $\mathrm{F}_{1}$ female individuals will appear and the per cent of nonviable eggs should decrease (table 8). Although the per cent of nonviable eggs decreased after introducing the normal male into each cage, nearly all eggs laid developed into males. The females produced were small, light-colored, and lethargic. The $\mathrm{F}_{1}$ females appearing most normal were caged with a normal male and their $\mathrm{F}_{2}$ egg production and viability was observed. In all cases, the female either did not lay eggs or, if she did, they were always sterile. This indicated that the parental females did not receive a second sperm complement competitive with the first. It does not prove, however, that they did not mate more than once, but for practical purposes, a single mating may be assumed for the females in each of the five replicates.

The reciprocal to this experiment was also conducted; that is, a normal male was caged with a virgin female for one 
TABLE 8

CHANGES IN VIABILITY, PER CENT $F_{1}$ FEMALES, AND APPEARANCE OF $F_{1}$ FEMALES AS INDICATIONS OF MULTIPLE MATINGS OF NORMAL FEMALE TWO-SPOTTED MITES AFTER A STERILE MALE WAS REPLACED BY A NORMAL MALE

\begin{tabular}{|c|c|c|c|c|c|}
\hline \multirow{2}{*}{$\begin{array}{l}\text { Identification of } \\
\text { normal female }\end{array}$} & \multicolumn{2}{|c|}{ Eggs produced } & \multirow{2}{*}{$\underset{\text { mites }}{\text { Female } F_{1}}$} & \multirow{2}{*}{$\begin{array}{l}\text { Longevity } \\
\text { of females }\end{array}$} & \multirow{2}{*}{$\begin{array}{l}\text { Indication of } \\
\text { multiple } \\
\text { mating }\end{array}$} \\
\hline & Total & Nonviable & & & \\
\hline Caged with sterile & Number & Per cent & Per cent & Days & \\
\hline No. $1 \ldots \ldots \ldots \ldots \ldots$ & 33 & 18.2 & $3.6 t$ & & \\
\hline 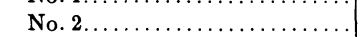 & 77 & 71.4 & $4.5 \dagger$ & $\begin{array}{l}\cdots \\
\ldots\end{array}$ & $\begin{array}{l}\cdots \\
\ldots\end{array}$ \\
\hline No. $3 \ldots \ldots \ldots \ldots \ldots \ldots \ldots \ldots$ & 60 & 55.0 & 0.0 & .. & . \\
\hline No. $4 \ldots \ldots \ldots \ldots \ldots$ & 72 & 69.4 & 0.0 & . & . \\
\hline No. $5 \ldots \ldots \ldots \ldots \ldots \ldots$ & 30 & 66.7 & $10.0 \dagger$ & . & . \\
\hline $\begin{array}{l}\text { Then caged with } \\
\text { normal male replacement: }\end{array}$ & & & & & \\
\hline No. $1 \ldots \ldots \ldots \ldots \ldots \ldots \ldots$ & 221 & 52.5 & $11.1 \dagger$ & 35 & no \\
\hline No. $2 \ldots \ldots \ldots \ldots \ldots \ldots$ & 79 & 38.0 & $4.1 \dagger$ & 19 & no \\
\hline No. $3 \ldots \ldots \ldots$ & 193 & 36.3 & $1.6 \dagger$ & 39 & no \\
\hline No. $4 \ldots \ldots \ldots \ldots \ldots \ldots \ldots \ldots$ & 121 & 37.2 & 0.0 & 31 & no \\
\hline No. $5 \ldots \ldots \ldots \ldots \ldots \ldots \ldots$ & 233 & 48.5 & $6.7 \dagger$ & 39 & no \\
\hline
\end{tabular}

* Male irradiated with $25 \mathrm{krads}$.

$\dagger F_{1}$ females small, light-colored, lethargic. When mated with normal males, no eggs were laid, or eggs were sterile.

week, after which the male was replaced with one that had been irradiated with 25 krads. More nonviable eggs should have been observed if the sperm complement from a subsequent mating to the sterile male is competitive with the first (table 9). In one of five replicates the per cent of nonviable eggs increased to 20.3 per cent. None of the other four replicates exceeded 4.5 per cent nonviability, which is well within the norm. Thus, one out of five females was probably fertilized successfully a second time. Data from these two experiments indicate that this occurs in about 10 per cent of the females.

The number of matings by a single male was also determined, as this could be important in determining the number of sterile males to be released into a field population for control. Eight quiescent deutonymph females were caged and allowed to emerge in the presence of a single male. After 24 hours the male was removed and each female placed in a separate cage and observed. If the females mated, they will, of course, lay fertilized eggs that will result in $F_{1}$ females. A second group of seven quiescent deutonymph females was caged with a single male for 48 hours. These females were also put into individual cages and observed. Data from these experiments (table 10) support the observations of Smith, Boswell, and Henneberry (1965) on multiple matings of males.

In the first case, where the male was allowed to remain in the cage for 24 hours, seven of the eight females were mated, and of the seven, six had suffcient sperm for their entire lives. When the male was allowed to remain for 48 hours with seven females, they were all inseminated with sufficient sperm for life. Thus, a single male can effectively inseminate many females in a fairly short period of time, given the opportunity.

\section{Mating competitiveness of sterile vs. normal males}

If a field release of sterile males is to cause a decline in population, sterile males must be as competitive for mates as are normal males. Both a sterile (ex- 
TABLE 9

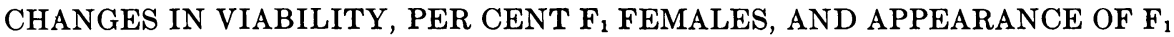
FEMALES AS INDICATIONS OF MULTIPLE MATINGS OF NORMAL

FEMALE TWO-SPOTTED MITES AFTER A NORMAL MALE WAS REPLACED BY A STERILE MALE

\begin{tabular}{|c|c|c|c|c|c|}
\hline \multirow{2}{*}{$\begin{array}{l}\text { Identification of } \\
\text { normal female }\end{array}$} & \multicolumn{2}{|c|}{ Eggs produced } & \multirow{2}{*}{$\underset{\text { mites }}{\text { Female }} F_{1}$} & \multirow{2}{*}{$\begin{array}{l}\text { Longevity } \\
\text { of females }\end{array}$} & \multirow{2}{*}{$\begin{array}{c}\text { Indication of } \\
\text { multiple } \\
\text { mating }\end{array}$} \\
\hline & Total & Nonviable & & & \\
\hline Caged with normal & Number & Per cent & Per cent & Days & \\
\hline male for one week: & & & & & \\
\hline No. $1 \ldots \ldots \ldots \ldots$ & 62 & 4.8 & 47.5 & . & . \\
\hline No. $2 \ldots \ldots \ldots \ldots \ldots \ldots \ldots \ldots$ & 73 & 0.0 & 46.6 & . & . \\
\hline No. $3 \ldots \ldots \ldots \ldots \ldots \ldots \ldots \ldots$ & 29 & 0.0 & 69.0 & . & . \\
\hline No. $4 \ldots \ldots \ldots \ldots \ldots \ldots \ldots \ldots$ & 35 & 0.0 & 68.6 & . & . \\
\hline No. $5 \ldots \ldots \ldots \ldots \ldots \ldots \ldots \ldots$ & 26 & 0.0 & $\ldots \dagger$ & . & . \\
\hline $\begin{array}{l}\text { Then caged with } \\
\text { gterile male replacement:* }\end{array}$ & & & & & \\
\hline No. $1 \ldots \ldots \ldots \ldots \ldots \ldots \ldots$ & 135 & 1.5 & $36.8 \ddagger$ & 35 & no \\
\hline No. $2 \ldots \ldots \ldots \ldots \ldots \ldots \ldots \ldots \ldots$ & 137 & 4.4 & $44.8 \ddagger$ & 19 & no \\
\hline No. $3 \ldots \ldots \ldots \ldots \ldots \ldots \ldots \ldots$ & 219 & 4.6 & $45.5 \ddagger$ & 31 & no \\
\hline No. $4 \ldots \ldots \ldots \ldots \ldots \ldots \ldots \ldots \ldots$ & 118 & 20.3 & $74.5 \ddagger$ & 198 & yes \\
\hline No. $5 \ldots \ldots \ldots \ldots \ldots \ldots \ldots$ & 172 & 1.2 & $55.3 \ddagger$ & $23 \S$ & no \\
\hline
\end{tabular}

* Male irradiated with 25 krads.

$t$ Leaf desiccated.

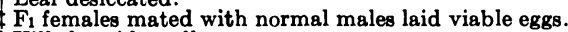

Killed accidentally.

TABLE 10

NUMBER OF MATINGS BY SINGLE MALE TWO-SPOTTED MITES WHEN PRESENTED WITH SEVERAL VIRGIN FEMALES FOR PERIODS OF 24 AND 48 HOURS, AS DETERMINED BY THE $F_{1}$ SEX RATIO

\begin{tabular}{|c|c|c|c|c|c|c|c|}
\hline \multirow{2}{*}{ Identification of male } & \multicolumn{3}{|c|}{ Eggs produced } & \multicolumn{2}{|c|}{ Sex of $F_{1}$} & \multirow{2}{*}{$\begin{array}{l}\text { Longevity } \\
\text { of female }\end{array}$} & \multirow{2}{*}{$\begin{array}{c}\text { Female } \\
\text { successfully } \\
\text { inseminated } \\
\text { for life }\end{array}$} \\
\hline & Total & Non & iable & Male & Female & & \\
\hline $\begin{array}{l}\text { Caged singly for } 24 \text { hours with eight } \\
\text { quiescent, deutonymph females: }\end{array}$ & Number & Number & Per cent & \multicolumn{2}{|c|}{ Per cent } & Days & \\
\hline No. $1 \ldots \ldots \ldots \ldots \ldots \ldots \ldots \ldots \ldots$ & 101 & 0 & 0.0 & 48.5 & 51.5 & $14^{*}$ & yes \\
\hline No. $2 \ldots \ldots \ldots \ldots \ldots \ldots \ldots \ldots$ & 235 & 22 & 9.4 & 42.7 & 57.3 & 33 & yes \\
\hline No. $3 \ldots \ldots \ldots \ldots \ldots \ldots \ldots \ldots \ldots$ & 218 & 12 & 5.5 & 98.1 & 1.9 & 33 & no \\
\hline No. $4 \ldots \ldots \ldots \ldots \ldots \ldots \ldots \ldots$ & 215 & 3 & 1.4 & 40.0 & 60.0 & 29 & yes \\
\hline No. $5 \ldots \ldots \ldots \ldots \ldots \ldots \ldots \ldots \ldots$ & 211 & 14 & 6.6 & 100.0 & 0.0 & 29 & no \\
\hline No. $6 \ldots \ldots \ldots \ldots \ldots \ldots \ldots \ldots \ldots$ & 134 & 3 & 2.3 & 51.2 & 48.8 & 19 & yes \\
\hline No. $7 \ldots \ldots \ldots \ldots \ldots \ldots \ldots$ & 153 & 10 & 6.5 & 55.3 & 44.7 & 19 & yes \\
\hline No. $8 \ldots \ldots \ldots \ldots \ldots \ldots \ldots \ldots$ & 150 & 13 & 8.7 & 57.8 & 42.2 & 29 & yes \\
\hline $\begin{array}{l}\text { Caged singly for } 48 \text { hours with seven } \\
\text { quiescent, deutonymph females: }\end{array}$ & & & & & & & \\
\hline No. $1 \ldots \ldots \ldots \ldots \ldots \ldots \ldots \ldots$ & 176 & 4 & 2.3 & 45.9 & 54.1 & 23 & yes \\
\hline No. $2 \ldots \ldots \ldots \ldots \ldots \ldots \ldots \ldots$ & 129 & 2 & 1.6 & 46.4 & 53.6 & 19 & yes \\
\hline No. $3 \ldots \ldots \ldots \ldots$ & 193 & 22 & 11.4 & 53.9 & 46.1 & 23 & yes \\
\hline No. $4 \ldots \ldots \ldots \ldots \ldots$. & 91 & 1 & 1.1 & 37.7 & 62.3 & 14 & yes \\
\hline No. $5 \ldots \ldots \ldots \ldots \ldots \ldots$ & 146 & 2 & 1.4 & 34.5 & 65.5 & 28 & yes \\
\hline No. $6, \ldots \ldots \ldots \ldots, \ldots, \ldots, \ldots$, & 172 & 5 & 2.9 & 65.1 & 34.9 & 28 & yes \\
\hline No. $7 \ldots \ldots \ldots \ldots \ldots \ldots \ldots \ldots$ & 157 & 2 & 1.3 & 70.1 & 29.9 & 28 & yes \\
\hline
\end{tabular}

* Killed accidentally. 
TABLE 11

SPIDER MITE PRODUCTION AND EGG VIABILITY OF 45 VIRGIN FEMALES EACH CAGED FOR 72 HOURS SIMULTANEOUSLY WITH A STERILE AND A NORMAL MALE FOR ASSESSMENT OF MATING COMPETITIVENESS

\begin{tabular}{|c|c|c|c|c|}
\hline \multirow{2}{*}{ Females mated with: } & \multirow{2}{*}{$\begin{array}{c}\text { Number of } \\
\text { matings }\end{array}$} & \multicolumn{2}{|c|}{ Eggs $\dagger$} & \multirow{2}{*}{$\begin{array}{l}\text { Sex of } F_{1} \\
\text { progeny }\end{array}$} \\
\hline & & $\begin{array}{l}\text { Average number } \\
\text { per female }\end{array}$ & $\begin{array}{c}\text { Per cent } \\
\text { nonviable }\end{array}$ & \\
\hline Normal males................... & 21 & $\begin{array}{c}99.3 \\
(7-148)\end{array}$ & $\begin{array}{c}1.1 \\
(0.0-10.0)\end{array}$ & $\mathrm{M}+\mathrm{F}$ \\
\hline Sterile males. & 19 & $\begin{array}{c}97.4 \\
(45-136)\end{array}$ & $\begin{array}{c}54.2 \\
(38.8-71.2)\end{array}$ & M only \\
\hline Both normal and sterile males*. & 5 & $\begin{array}{l}112.4 \\
(59-133)\end{array}$ & $\begin{array}{c}23.8 \\
(15.3-39.8)\end{array}$ & $\mathrm{M}+\mathrm{F}$ \\
\hline
\end{tabular}

- It was assumed that any female that laid over 15 per cent nonviable eggs and produced both male and female progeny had mated with both males.

t Numbers in parentheses indicate ranges.

posed to $25 \mathrm{krads}$ ) and a normal male were caged with a quiescent deutonymph female for 72 hours, after which the males were removed and the per cent nonviability of the $F_{1}$ eggs recorded (table 11). Females were not held until their death, but only long enough to determine with which male they had mated. Of the 45 replicate females, 21 (47 per cent) mated with the normal male, 19 (42 per cent) with the sterile male, and five (11 per cent) apparently with both males. When both males and females appeared in the $F_{1}$ generation, and the per cent of nonviable eggs was somewhat higher than expected for a normal mating, it was difficult to know whether both males mated with the female, or if this particular female had an abnormally high per cent of nonviable eggs. It was assumed that any female that laid over 15 per cent nonviable eggs and produced both normal male and female progeny, had mated with both males. The per cent that underwent multiple matings was about the same as that observed in previous experiments. It may be concluded that no preference is demonstrated by a female having the opportunity of mating either with a sterile or a normal male.

\section{Mating compatibility of field and laboratory strains}

Conceivably, a strain of mites confined to a laboratory rearing situation for many years may not be as compatible for mates as those of the field strain. To determine whether mating occurred readily between the field and laboratory strains, several late-quiescent deutonymph females from the field strain were placed one to a cage with a laboratory male and observed until emergence. In every case, the laboratoryreared males copulated with the females within 60 seconds after the females had undergone their final moult. All $\mathrm{F}_{1}$ eggs were viable, and a normal sex ratio was observed in the progeny.

\section{GREENHOUSE STUDIES: RESULTS AND DISCUSSION}

Twelve mite-free strawberry plants (Fresno variety) were selected for their uniform size and vigor. A release of normal mites was made to simulate an endemic population of a certain size. Ten adult males, 10 adult females, and 
TABLE 12

MEAN NUMBER OF TWO-SPOTTED MITES IN VARIOUS DEVELOPMENTAL STAGES ON STRAWBERRY PLANTS INOCULATED WITH "NORMAL" ENDEMIC POPULATIONS COMPARED TO POPULATIONS WHEN PLANTS RECEIVED ADDITIONAL STERILE MITES*

\begin{tabular}{|c|c|c|c|c|c|}
\hline \multirow{2}{*}{$\begin{array}{l}\text { Sex and developmental } \\
\text { stage }\end{array}$} & \multicolumn{5}{|c|}{ Mean numberst on following dates in $1968 \ddagger$} \\
\hline & Feb. 3 & Feb. 10 & Feb. 17 & Feb. 24 & Mar. 9 \\
\hline \multicolumn{6}{|l|}{ Males: } \\
\hline Check............... & 0.6 & 1.5 & 6.4 & 22.0 & $\cdots$ \\
\hline Experimental. ......... & 1.8 & 1.4 & 6.6 & 15.0 & 12.4 \\
\hline \multicolumn{6}{|l|}{ Females: } \\
\hline Check.............. & 0.7 & 1.4 & 24.5 & 30.7 & $\ldots$ \\
\hline Experimental. ......... & 5.0 & 5.8 & 27.0 & 16.3 & 7.3 \\
\hline \multicolumn{6}{|l|}{ Immatures: } \\
\hline Check. . . . . . . . & 1.4 & 21.2 & 28.6 & 444.8 & $\ldots$ \\
\hline Experimental. ......... & 1.8 & 7.1 & 23.1 & 149.7 & 8.8 \\
\hline \multicolumn{6}{|l|}{ Egga: } \\
\hline Check............... & 15.0 & 20.1 & 332.1 & 587.3 & $\cdots$ \\
\hline Experimental......... & 62.6 & 57.5 & 255.9 & 178.0 & 0.4 \\
\hline
\end{tabular}

* Each of 12 plants was inoculated with 40 normal individuals (10 adult males, 10 adult females, and 20 immatures) on January 26,1968 . On the same date, six of the 12 plants were inoculated with 360 sterile mites (90 adult males, 90 adult females, and 180 immature stages); these were the "experimental" plants. Remaining plants were "checks."

$\dagger$ Mites from 30 leaflets (five from each of six plants in both experimental and check groups) were counted.

$\ddagger$ Counts in check group were terminated on February 24, because large populations had so damaged plants that resulting loss of food source would be primary cause of population drop.

20 immature postembryonic stages of unknown sex were released on each of the twelve plants. Six of these plants served as controls, while releases of sterile mites were made on the remaining six plants. A release made at a ratio of nine sterile for every normal individual was made on the latter group of plants. Thus, 90 adult males, 90 adult females, and 180 immature post-embryonic stages of unknown sex were irradiated with 25 krads and released on each plant. The initial release was made on January 26, 1968, with a second release on February 10. The second release consisted of the same numbers of sterile mites as the first release. Population counts were made on February $3,10,17,24$, and March 9, 1968. Counts on February 10 were made before the second release of sterile mites. All stages of mites were counted on five leaflets from each plant. Old sterile eggs were not counted on those plants which had received the sterile mites. Table 12 gives the counts made on the check plants and the sterile-mite release plants. Averages of all 30 leaflets from each weekly count are graphically illustrated to show the trends of growth or decline of the populations in time (fig. 4).

A limited sample from the check plants was counted on February 24. Extremely high numbers of mites, their extensive webbing, and numerous cast skins, made an accurate count on these plants difficult to obtain. Leaves were so debilitated from the feeding activity of so many mites that plant growth had nearly ceased. As a result, counts were terminated on February 24 and the plants discarded. The plants inoculated with sterile mites were also damaged from feeding activity, but populations on February 24 were not as high as they were on the check plants. These plants were held for two more weeks, at the end of which time it was found that the population had declined to extremely low numbers. The following factors led us to believe this was due to the effect of the sterile individuals that had been released: (1) 


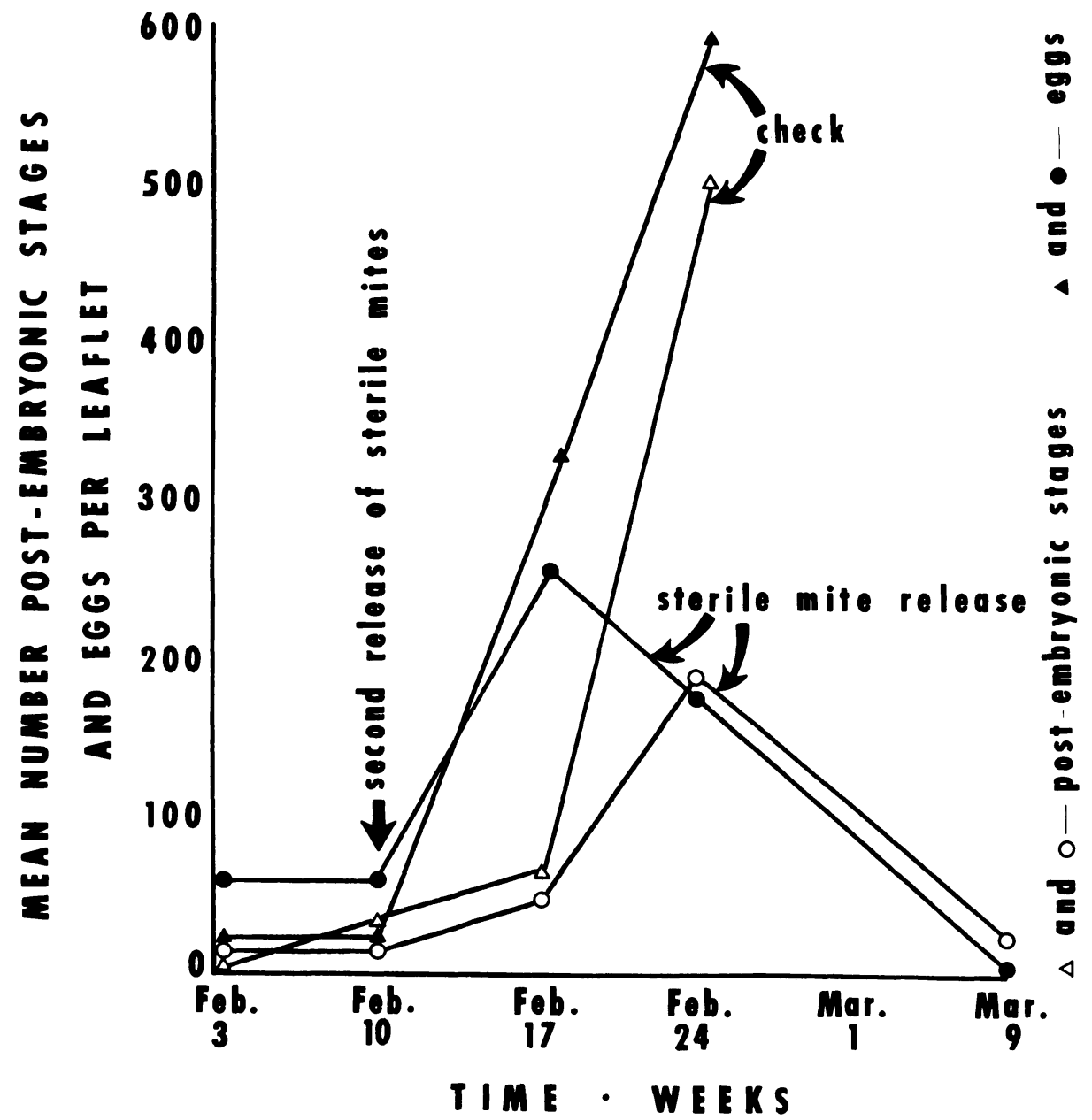

Fig. 4. Average number of post-embryonic stages and eggs of the two-spotted mite per leaflet on a group of check strawberry plants vs. a group on which releases of sterile mites were made.

numerous nonviable eggs were found on the leaflets; (2) there were nearly twice as many adult males as females; (3) females present were translucent and had no dark lateral spots, indicating that they may have been the result of a damaged sperm uniting with an egg to form a sterile $F_{1}$ female, (as described in the section on laboratory results) ; and (4) the proper time element had lapsed for an expected population decrease. If several normal females were mated with sterile males, one would expect an increase in the number of $F_{1}$ males in the population. With a two-week period for one generation and an adult longevity of from three to four weeks, a population decline about six weeks after the initial release would be expected. On the assumption that the population decline in the greenhouse test was due to the sterile-mite effect, a release ratio of nine sterile to one normal mite was chosen for the first field experiment. 


\section{FIELD STUDY 1-RELEASE OF STERILE INDIVIDUALS, BOTH SEXES}

\section{Plot design}

The plot was situated in a commercial strawberry planting of the Nedspride variety (a patented variety of Driscoll Strawberry Associates, Inc.) planted in late August, 1967, in Watsonville. The experiment consisted of four treatments and an untreated check, each replicated eight times in a randomized complete block design. Five 10 -foot rows of a single-bed planting comprised each replicate with the plants spaced 1 foot apart. Yield data and mite counts were taken from the center rows to avoid contamination from adjacent treatments caused by spray drift or lateral movement of the mites. Treatments were:

(1) A release of sterile mites of both sexes at an approximate ratio of $9: 1$ (sterile:normal) on March 27, 1968.

(2) A release of sterile mites on March 27, 1968, of both sexes at a $9: 1$ ratio, with two subsequent applications of naled (Dibrom ${ }^{\circledR}$ ) at an equivalent rate of one pound active ingredient in 150 gallons of water per acre. These applications were made on April 8 and 22, 1968. As the released mites were from a miticide-susceptible strain, it was thought that killing most of them two weeks after their introduction might help to stimulate plant growth by reducing feeding pressure. By this time many of the endemic miticide-resistant mites of the field strain would have mated with sterile males, and a subsequent decline in the population should follow. All chemical applications were made with a small bicycle-wheeled testplot sprayer at a pressure of 60 to 70 psi.

(3) Two applications of naled, corresponding to those in treatment 2 were made on the same dates. No mites were released.

(4) The grower's own control efforts in his commercial operation:

(a) March 12. Endosulfan and dicofol at 2 pounds active ingredient each in 150 gallons of water per acre.

(b) April 8. Naled, dicofol, and sulfur applied as a dust formulation at 2,2 , and 15 pounds active ingredient per acre, respectively.

(c) April 24. Naled and dicofol as a dust formulation at 2 pounds active ingredient each per acre.

(d) May 3. Same as (c).

(5) A check that had no releases of sterile mites or chemical applications.

\section{Data collection and sequential sampling}

The degree of control or lack of control is easily ascertained from a limited sample, if the population reacts decisively to a particular treatment. If an obvious trend is not expected in a short time, a larger sample is necessary to evaluate the results. Sampling just one leaflet per plant per week may affect subsequent results because of loss of leaves. Decline in population in a release area would not be anticipated until several of the released individuals had died; and thus population changes from week to week would probably not be extreme. Small changes that might occur in the population from releases were not considered important in determining an economic level of control. For these reasons, a sequential sampling plan was devised in which population levels were arbitrarily divided into 


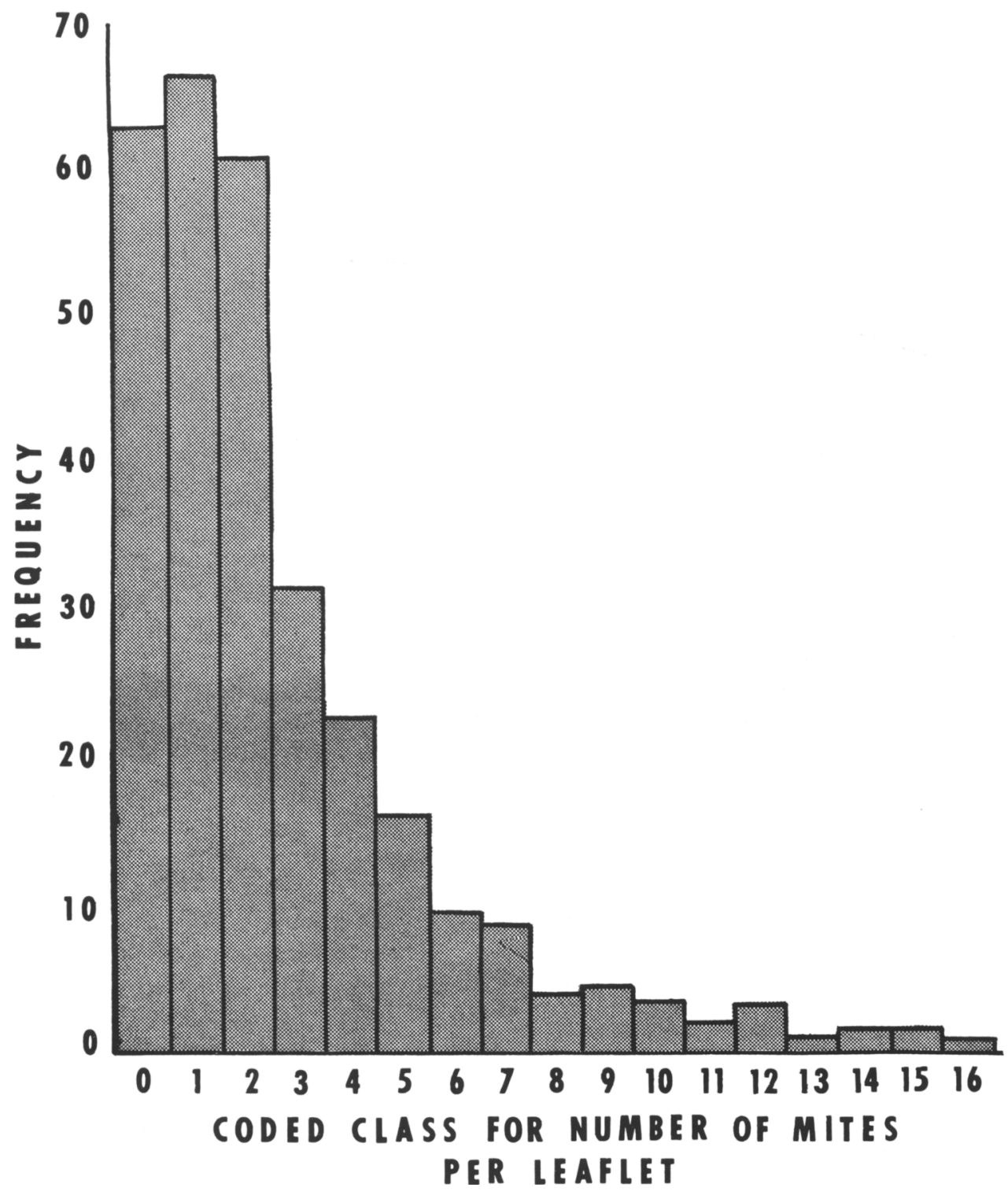

Fig. 5. Frequency histogram illustrating the negative binomial distribution of post-embryonic stages of the two-spotted mite on strawberry plants (Nedspride variety) on March 22, 1968, just before release of sterile mites, Watsonville, California.

light, moderate, and severe infestations. Because economic levels of mites on strawberries have never been established, these limits were set strictly on the basis of field observations made over the previous two years. Sequential sampling allows population levels to be de- termined from a limited sample size with the assurance that the result is as statistically sound as one from a very large sample. Statistical calculations involved in establishing this sequential sampling plan follow.

The initial step before release was to 
TABLE 13

COMPARISON OF OBSERVED FREQUENCY DISTRIBUTION OF TWO-SPOTTED MITES ON 319 LEAFLETS WITH THAT OF THEORETICAL VALUES CALCULATED FOR A NEGATIVE BINOMIAL DISTRIBUTION*

\begin{tabular}{|c|c|c|c|c|c|c|}
\hline $\begin{array}{c}\text { Number of } \\
\text { mites per } \\
\text { leaflet }\end{array}$ & $\begin{array}{c}\text { Coded } \\
\text { class } \\
(x)\end{array}$ & $\begin{array}{l}\text { Observed } \\
(f)\end{array}$ & $f x$ & $\begin{array}{l}\text { Accumulated } \\
\text { frequency } \\
\left(A_{x}\right)\end{array}$ & $\begin{array}{l}\text { Expected } \\
\text { frequency } \\
\underset{(\phi)}{ }\end{array}$ & $\frac{(f-\phi)^{2}}{\phi}=X^{2}$ \\
\hline $0-5$. & 0 & 64 & 0 & 255 & 72.30 & 0.9528 \\
\hline $6-10 \ldots \ldots \ldots \ldots$ & 1 & 68 & 68 & 187 & 60.23 & 1.0023 \\
\hline $11-15 \ldots \ldots \ldots \ldots$ & 2 & 62 & 124 & 125 & 46.93 & 4.8392 \\
\hline $16-20 \ldots \ldots \ldots \ldots$ & 3 & 32 & 96 & 93 & 35.73 & 0.3178 \\
\hline $21-25 \ldots \ldots \ldots \ldots$ & 4 & 23 & 92 & 70 & 26.88 & 0.5600 \\
\hline $26-30 \ldots \ldots \ldots \ldots$ & 5 & 17 & 85 & 53 & 20.07 & 0.4696 \\
\hline $31-35 \ldots \ldots \ldots \ldots$ & 6 & 12 & 72 & 41 & 14.92 & 0.5714 \\
\hline $36-40 \ldots \ldots \ldots \ldots$ & 7 & 11 & 77 & 30 & 11.05 & 0.0002 \\
\hline $41-45 \ldots \ldots \ldots \ldots$ & 8 & 4 & 32 & 26 & 8.14 & 2.1056 \\
\hline $46-50 \ldots \ldots \ldots \ldots$ & 9 & 5 & 45 & 21 & 6.00 & 0.1666 \\
\hline $51-55 \ldots \ldots \ldots \ldots$ & 10 & 4 & 40 & 17 & 4.42 & 0.0399 \\
\hline $56-60 \ldots \ldots \ldots \ldots$ & 11 & 2 & 22 & 15 & 3.25 & 0.4807 \\
\hline $61-65 \ldots \ldots \ldots \ldots$ & 12 & 4 & 48 & 11 & 2.39 & 1.0845 \\
\hline $66-70 \ldots \ldots \ldots \ldots$ & 13 & 1 & 13 & 10 & 1.75 & 0.3214 \\
\hline $71-75 \ldots \ldots \ldots \ldots$ & 14 & 2 & 28 & 8 & 1.28 & 0.4050 \\
\hline $76-80 \ldots \ldots \ldots \ldots$ & 15 & 2 & 30 & 6 & 0.94 & 1.1953 \\
\hline $100-268 \ldots \ldots \ldots \ldots$ & 16 & 6 & 96 & 0 & 2.80 & 3.6571 \\
\hline
\end{tabular}

* See pages $327-328$ for method of calculation. Values were established as follows:

$N=319, s^{2}=12.1277, S(f x)=966, X^{2}=18.1694, \bar{x}=3.0344$, estimated $k(k)=1.1483$

ascertain how mites were distributed in the field, as this ultimately determines the formulae to be used in calculating lines delineating the three levels of infestation. This was accomplished by collecting and evaluating a large sample of leaves to determine the endemic mite population and its distribution. One "middle-aged" leaflet from each of 319 plants was selected (very young and very old leaves were rejected), and the males, females, immatures, and eggs were counted. Figure 5 shows the population distribution as it was on March 27,1968 , just before release. Obviously, the mites were not distributed in a statistically "normal" fashion. Frequency distribution of mites on the 319 leaflets is given in the first three columns of table 13. If every leaf sampled were exposed equally to the chance of containing the organism, the distribution would follow the Poisson series, with each leaflet having the population mean as its expected frequency. Since the expected variance of a Poisson distribution is equal to its mean, the observed variance $\left(s^{2}\right)$, multiplied by the degree of freedom $(n)$, may be divided by the sample mean $(\bar{x})$ to obtain chi-square $\left(X^{2}\right)$, (i.e., $\left.X^{2}=n s^{2} / \bar{x}\right), \quad$ (Bliss and Fisher, 1953). Insects are often distributed such that the $X^{2}$ value is significantly larger than its expectation. In such cases, the distribution no longer fits the Poisson series. To determine if these data (table 13) fit a Poisson distribution the observed variance $\left(s^{2}\right)$ was computed from the basic sums beneath the table, where, as usual, the variance is computed from the formula

$$
s^{2}=\frac{S\left(f x^{2}\right)-S(f x)^{2} / N}{N-1} .
$$

The variance (12.1277) was found to be nearly four times as large as the mean (3.0344), thus indicating an overdispersion far too large to fit the Poisson series. However, the frequencies expected by the negative binomial, shown in column six of table 13, are much the same as the observed values. These expected values were calculated by the method of Bliss and Fisher (1953). The 
observed and expected frequencies were then compared by chi-square analysis, where chi-square has three fewer degrees of freedom than the number of ratios that are summed. A total contribution to chi-square of 18.1694 , with 13 degrees of freedom, shows agreement between the matched frequencies at the 5 per cent significance level.

The negative bionomial is completely defined by the two parameters $m$ (the arithmetic mean) and $k$ (a positive exponent). The expression $(q-p)^{-k}$, where $p=m / k$ and $q=1+p$, when expanded, describes the negative binomial. The term $k$ is a measure of the over-dispersion or aggregation. As populations tend toward greater aggregation, the mean $(\bar{x})$ and the variance $\left(s^{2}\right)$ become more divergent, and $k \rightarrow 0$. As $k \rightarrow$ infinity the $\bar{x}$ and $s^{2}$ converge, and the population assumes a more random distribution. As convergence continues, the population will assume a Poisson distribution when $\bar{x}$ equals $s^{2}$. The parameter $m$ is estimated efficiently from the statistical $\bar{x}$ where $\bar{x}=S(f x) / N$. The value of $k$ (1.1483) was determined by the method of maximum likelihood $(k)$ as described by Bliss and Fisher (1953). Theoretical evidence suggests that $k$ depends on the intrinsic ability of a species to reproduce itself, while $m$ depends on external factors. Therefore, $k$ should remain fairly constant within reasonable limits of $m$, for any one sampling method (Morris, 1954).

Having established that the population was distributed according to the negative binomial, a sequential sampling plan was devised following the method of Morris (1954). The infestation classes and their respective numerical limits were established as follows:

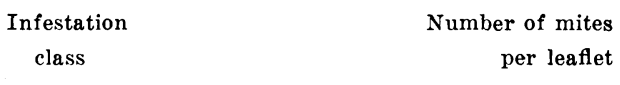

Light $\ldots \ldots \ldots \ldots \ldots \ldots \ldots \ldots \ldots$ or less Moderate .................. 25-50 Severe ................ 150 or more
In reference to these infestation classes, alternative hypotheses $\left(H_{0}\right.$ and $\left.H_{l}\right)$ may be established to distinguish between light and moderate and between moderate and severe infestations. Each pair of hypotheses is attended by two types of error, and the probability of committing either was set arbitrarily at 0.1 . Acceptance and rejection lines for the sequential sampling graph are calculated using the formulae $d=s n+H_{o}$ and $d=s n+H_{l}$, where $s$ equals the slope of the line, $n$ equals the leaflet number, and $H_{o}$ and $H_{l}$ are the intercepts. The acceptance and rejection lines are plotted for the light vs. moderate and moderate vs. severe infestation classes (fig. 6). This graph may now be used to determine how many leaflets should be sampled in each replicate of each treatment in order to define the infestation class within the accepted limits of error. As long as the cumulative number of mites falls within either of the two sets of lines, another leaflet must be sampled. This process continues until the cumulative value falls outside either set of lines, at which time the decision has been made and sampling is discontinued in that replicate. If ten leaflets are sampled and no decision has been reached, sampling is discontinued in that replicate and classified as an intermediate level of infestation.

\section{Mathematical models}

The theoretical basis for population control using the sterile-male technique was an essential part of Knipling's original work $(1955,1959,1960,1964)$. He constructed mathematical models for sierile-insect techniques that included releasing sterile individuals into a natural population, as well as sterilizing a portion of the natural population. Berryman (1967) submitted a mathematical description of the sterile-male technique which is not subject to certain limitations of Knipling's models. Knipling's models are limited by the assump- 


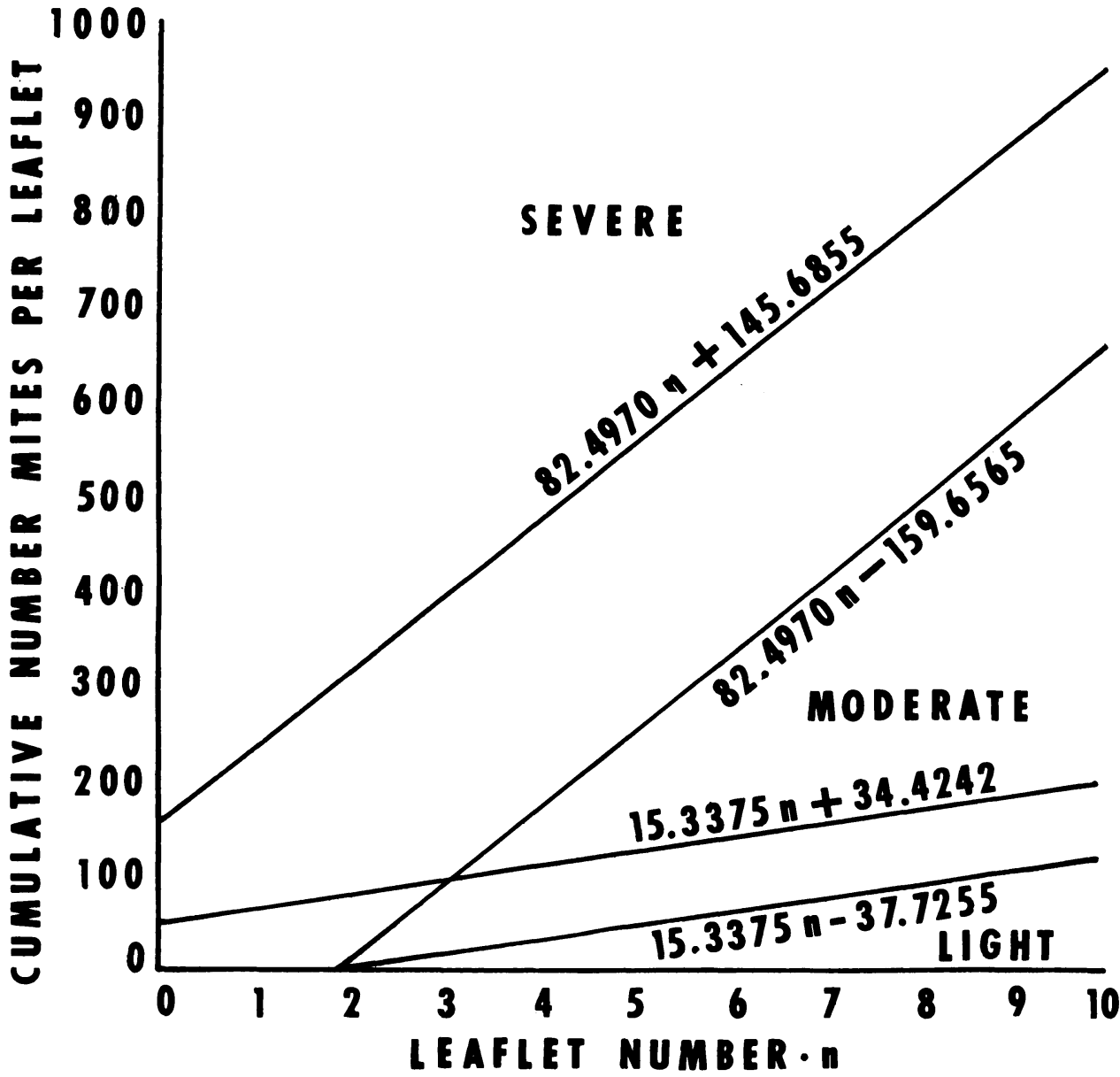

Fig. 6. Sequential sampling plan for a two-spotted mite population assuming a negative binomial distribution.

tions that females mate only once, and that the normal and sterile males are equally competitive in mating. The reproductive biology and behavior of the two-spotted mite lends itself to the more uncomplicated models as proposed by Knipling. We have modified his format to include the fact that mites feed and reproduce on the host plant for two generations. Four other assumptions apply to our models: (1) the females, in effect, mate only once; (2) sterile mites compete equally with normal mites in mating; (3) females mated to sterile males produce normal males; and (4) normal males mate several times.
Before a model can be constructed it is necessary to know the intrinsic rate of increase per generation for the biological entity that is being studied. This will vary tremendously, depending on the species and the environmental and biological conditions under which the population exists. In order to establish rate of change per generation, both the natality and mortality must be considered; this figure may vary considerably from crop to crop and from one geographic area to another, depending on weather, abundance of predators and parasites, and quantity and quality of food. Therefore, we consider a most important 
precept to any research program involving the sterile-male concept is a thorough knowledge of the reproductive biology of the species being investigated.

At best, one can determine what will occur under an assumed set of average conditions. If an actively feeding stage were not being released, then the maximum possible net reproductive rate could be used as a guideline in determining numbers of sterile individuals to be released. This is not practical with mites, however, since the goal is to accomplish as much population suppression with as few sterile mites as is possible. Therefore, one should determine the population dynamics per generation and see if a sufficient number of sterile mites is being released. It is important that this measurement should be made at a time when the population is increasing, because this is the time when control by chemicals, release of sterile males, or by other means, is most critical. Rate of growth also can indicate why a particular experiment with sterile-male releases may or may not be succeeding.

Table 14 shows that the mite populations in the untreated checks increased
TABLE 14

NET RATE OF GROWTH PER GENERATION FOR UNTREATED (CHECK) POPULATIONS OF THE TWO-SPOTTED MITE ON THE NEDSPRIDE STRAWBERRY VARIETY (FIELD STUDY 1)

\begin{tabular}{|c|c|c|}
\hline $\begin{array}{c}\text { Date of } \\
\text { count (1968) }\end{array}$ & $\begin{array}{l}\text { Average number } \\
\text { mites per leaflet* }\end{array}$ & $\begin{array}{l}\text { Rate of increase } \\
\text { per generation }\end{array}$ \\
\hline April $1 \ldots \ldots \ldots$ & 11.5 & $17.59 \times\left(\mathrm{P}_{1}\right)$ \\
\hline April $8 \ldots \ldots \ldots$ & 55.4 & \\
\hline April $15 \ldots \ldots \ldots$ & 202.3 & $0.67 \times\left(F_{1}\right)$ \\
\hline April $22 \ldots \ldots \ldots$ & 140.6 & $\ldots$ \\
\hline April $29 \ldots \ldots \ldots$ & 136.2 & $\ldots\left(\mathbf{F}_{\mathbf{2}}\right)$ \\
\hline May $6 \ldots \ldots \ldots$ & 97.8 & $\ldots$ \\
\hline
\end{tabular}

- Data represent an average from 20 leaflets from each of four replicates.

17.59 times in the first generation after the release was made. The average life span for an adult female is about 22 to 25 days. With approximately 14 days required to complete each generation (weekly mean temperature of $21 \pm 1^{\circ} \mathrm{C}$ ), it is obvious that 100 per cent mortality of the $\mathrm{P}_{1}$ generation does not occur until sometime during the $F_{2}$ generation. Thus, the net population increase per generation accounts for both natality and mortality during one generation.

Mathematical models (tables 15, 16, 17) based on these data from untreated

TABLE 15

THEORETICAL TREND OF A MITE POPULATION WHEN UNIMPEDED BY MITICIDES OR RELEASES OF STERILE MITES WITH RATES OF INCREASE BASED ON THOSE OBSERVED IN FIELD STUDY $1^{*}$

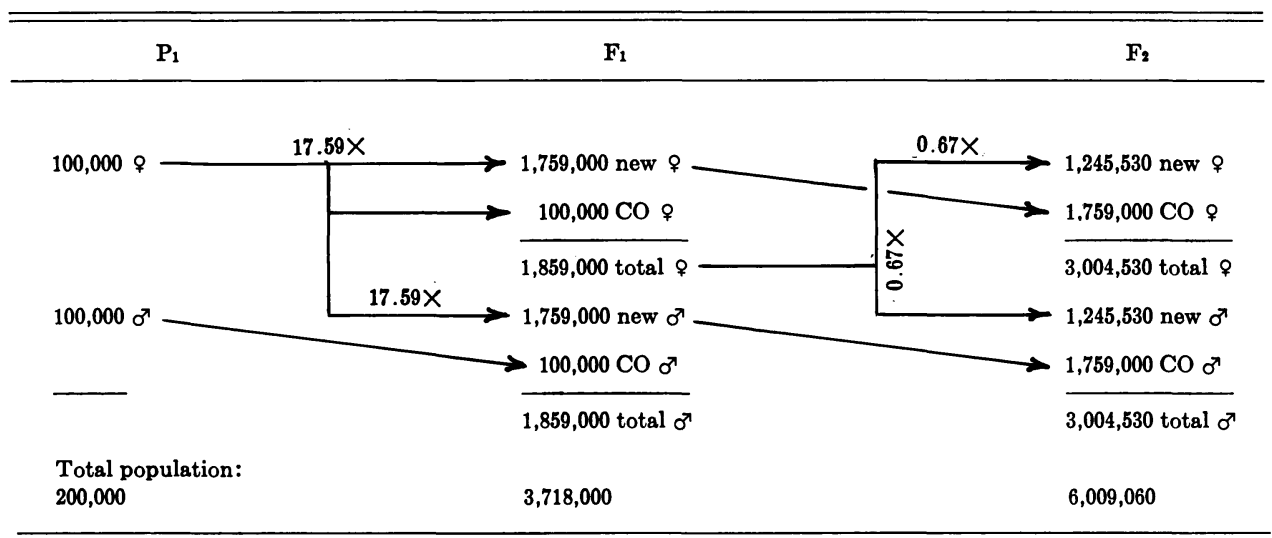

$* \mathrm{P} 1=17.59 \times$ and $\mathrm{F}_{1}=0.67 \times ; \mathrm{CO}=$ carry over 
TABLE 16

THEORETICAL TREND OF A MITE POPULATION SUBJECTED TO CONTROL BY MITICIDES RESULTING IN A MORTALITY OF 90 PER CENT PER GENERATION WITH SAME RATES OF INCREASE AS THOSE OBSERVED IN FIELD STUDY $1^{*}$

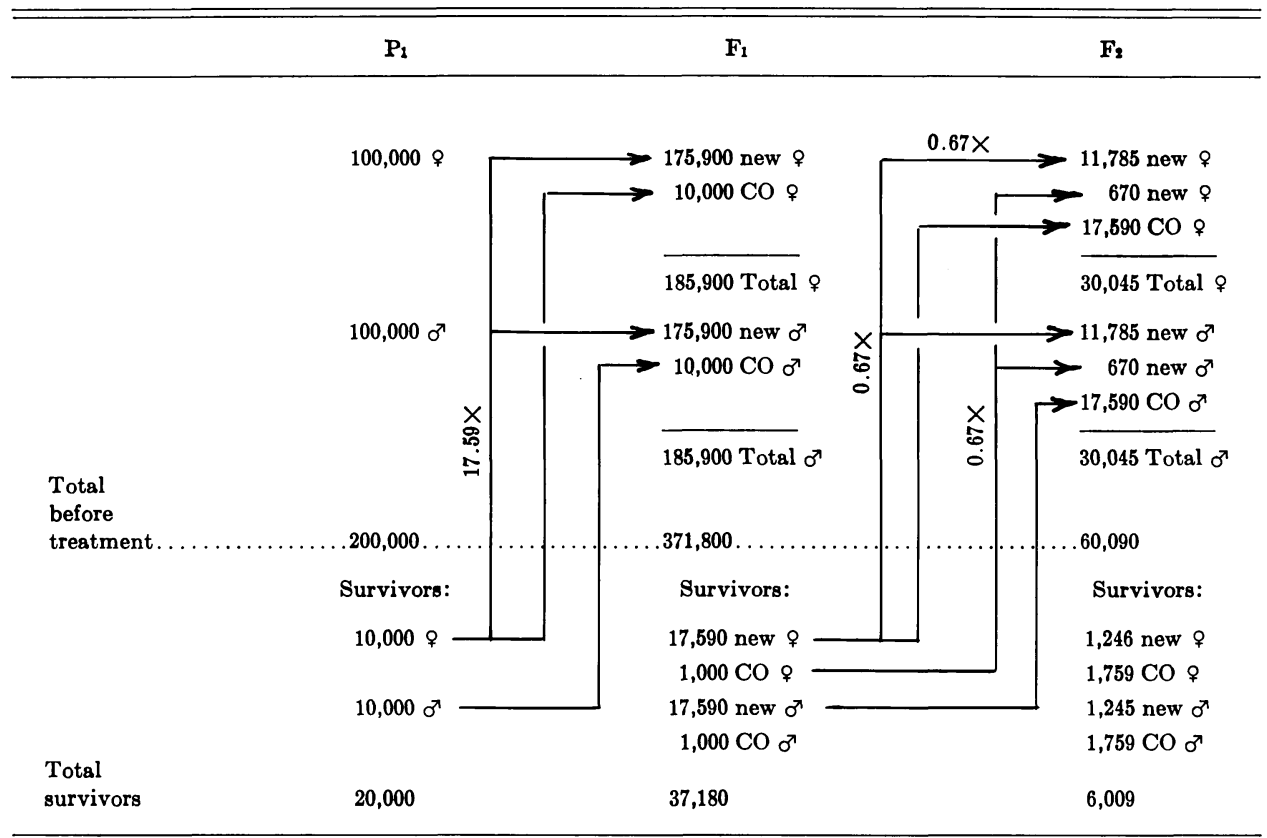

- $P_{1}=17.59 \times$ and $F_{1}=0.67 \times ; C O=$ carry over

checks were constructed for an unimpeded population growth, a 90 per cent kill per generation by a miticide, and a release of sterile mites at a 9:1 (sterile: normal) ratio for the population depicted in table 14.

From the models it is apparent that a single release of sterile-to-normal mites at a 9:1 ratio cannot compensate for a population that is expanding at a $17.59 \times$ rate per generation.

\section{Results and discussion}

Table 18 gives a summary of four counts made after the release, depicting the population density according to previously established infestation classes. The first horizontal row in this table records the number of replicates (out of a total of eight per treatment) in each class at the time of release. Notice that nearly half of the replicates in each treatment are rated as moderately infested ( 25 to 50 mites per leaflet). To compensate for this, tremendous numbers of sterile mites had to be released to meet the previously established standard of a 9:1 ratio. The mathematical model mentioned demonstrates that suppression from a 9:1 release ratio is an impossibility with a population expanding at $17.59 \times$ per generation (tables 14, 17). In addition, plants were severely affected from the added feeding pressure of released mites.

Yield data were collected with both the number of baskets picked and the weight of the fruit being recorded; a member of the actual field labor force was used in the picking tests to avoid bias. Yield data did not indicate any meaningful differences between treat- 
TABLE 17

THEORETICAL TREND OF A MITE POPULATION FOLLOWING A SINGLE RELEASE OF STERILE ADULTS OF BOTH SEXES WITH RATES OF INCREASE BASED ON THOSE OBSERVED IN FIELD STUDY $1 *$

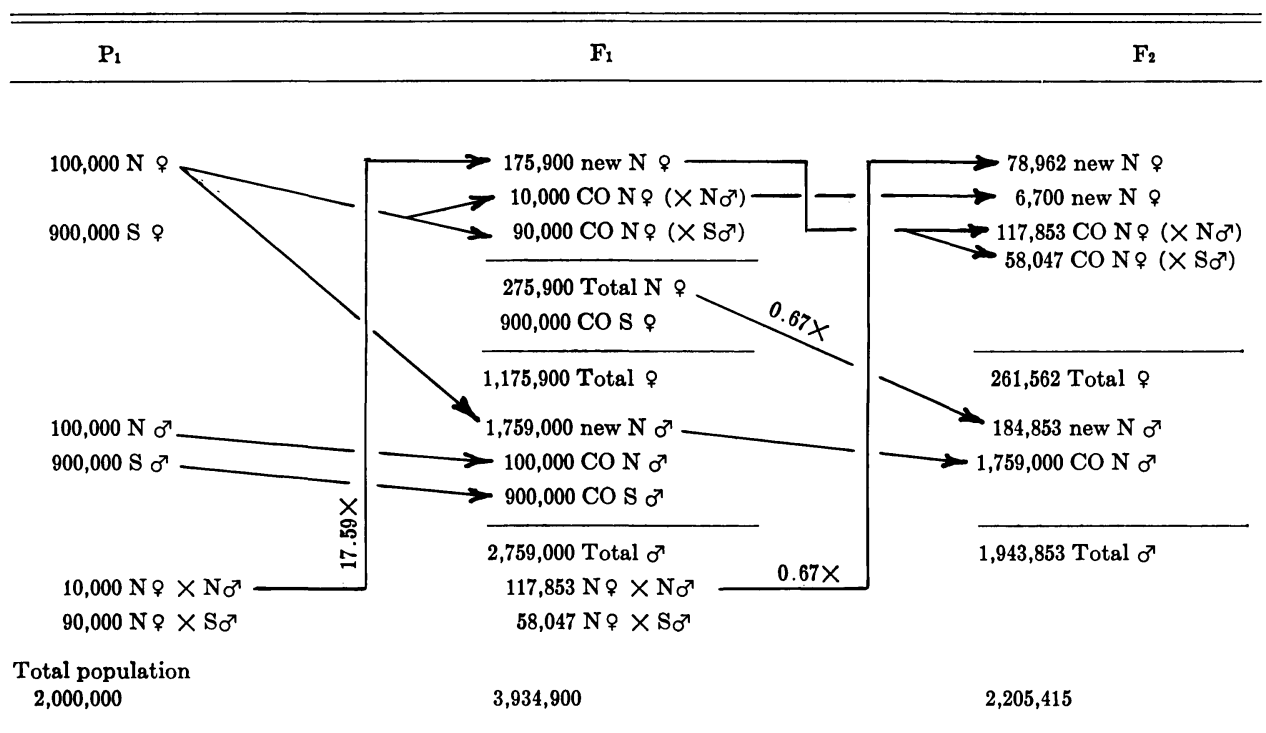
male.

$* \mathrm{P}_{1}=17.59, \mathrm{~F}_{1}=0.67 \times, \mathrm{CO}=$ carry over, $\mathrm{N}=$ normal, $\mathrm{S}=$ sterile, $\mathrm{N} q\left(X \mathrm{~S}^{\top}\right)=$ normal female mated with sterile

In $P_{1}$, the probability of a $\mathrm{N} \%$ or a $\mathrm{N}^{7}$ in any mating is $100,000 / 1,000,000$ or 0.1 . The probability of a $\mathrm{S} \&$ or a $\mathrm{S} \sigma{ }^{2}$ in any mating is $900,000 / 1,000,000$ or 0.9 . The probability of a No $\times \mathrm{No}^{7}$ mating is $0.1 \times 0.1$ or 0.01 . Of $1,000,000$ possible matings, 10,000 (i.e., 1,000,000 $\times 0.01$ ) should be $\mathrm{N} \% \times \mathrm{N}^{\top}$. The probability of a $\mathrm{N} \%$ S $\sigma^{7}$ mating is $0.1 \times 0.9$ or 0.09 Of 1,000,000 possible matings, 90,000 (i.e., 1,000,000 $\times 0.09$ ) should be $N$ \% $\times$ So' (producing $\mathrm{N}^{7}$ only). The other possible matings involve $\mathrm{S} \&$ which are infertile. In $\mathrm{F}_{1}$, the probability of a $\mathrm{N} \% \times \mathrm{No}^{7}$ mating is 0.67 and the calculated number of such matings is 117,853 . The calculated number of $\mathrm{N} \% \times \mathrm{S}^{7}$ matings is 58,047 .

ments. The experiment was terminated after six weeks, when it was apparent that this paritcular test was not going to suppress mite populations without undue damage to the plants. A second field trial was initiated, with several major differences imposed as a result of the experiences gained from the first test.

\section{FIELD STUDY 2-RELEASE OF STERILE MALES}

\section{Plot design}

The test plot was in a commercial planting of the Goldsmith variety (a patented variety of Driscoll Strawberry Associates, Inc.) that had been planted in December, 1967. Three treatments and an untreated check were included in a nonrandomized complete block design. If replicates had been randomized, mites may have moved from replicates of one treatment to those of another. Each replicate consisted of three beds (each bed having two rows) 10 feet long. Leaves used for mite population counts were of medium age, and were selected from plants on the center bed and the inside row of the two adjacent beds of each treatment. Yield data were collected from the center bed of each treatment by a member of the regular field-labor force every three to five days, and number of baskets and weight of fruit were recorded. Treatments were as follows:

(1) A release of approximately 19 sterile males to every normal male on 


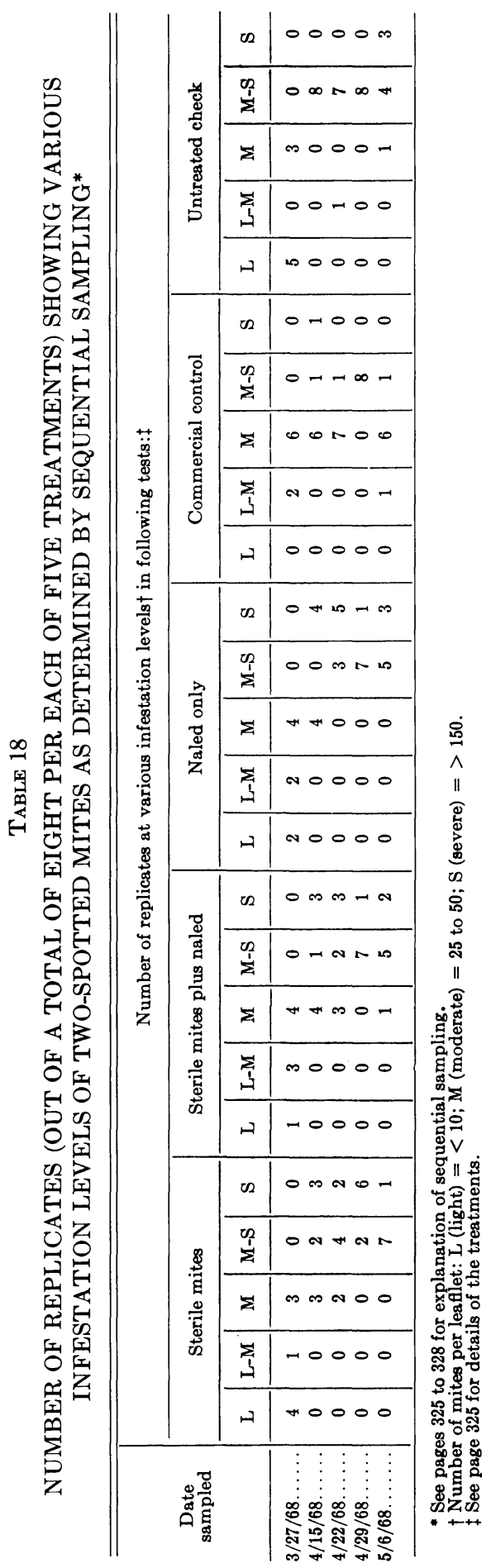


June 3, 1968, with subsequent releases of an equal number of sterile males each week through August 26.

(2) A release of 19 sterile males to every normal male on June 3, 1968, with an equal number of males released every other week through August 26.

(3) An evaluation of the grower's efforts at chemically controlling the mites in his commercial operation. All materials were applied by a ground sprayer with the exception of one air application on June 8, 1968. The chemicals, pounds of active ingredients, and application dates are as follows:

(a) May 20. Dicofol and naled at 2 pounds each in 200 gallons of water per acre.

(b) June 8. Mevinphos (Phos$\mathrm{drin}^{\circledR}$ ) at 1 pound in 10 gallons of water per acre by airplane. All other experimental plots were covered with a plastic tarp during and 12 hours after this application.

(c) June 12 and 29. Same as (a).

(d) July 16. Naled at 1 pound in 200 gallons of water per acre.

(e) July 30. Endosulfan and diazinon at 2 and 1 pounds, respectively, in 200 gallons of water per acre.

(f) August 6. Naled and carbophenothion (Trithion ${ }^{\circledR}$ ) at 1 and $11 / 2$ pounds, respectively, in 200 gallons of water per acre.

(g) September 1. Naled and dicofol at 1 and 2 pounds respectively, in 200 gallons of water per acre.

(4) A check which had no sterile mite release or chemical applications made on it for the duration of the experiment.

\section{Data collection and analysis}

Populations were evaluated every two weeks (with one exception) by counting the number of mites from 20 leaflets per replicate. All counts were made directly from the leaflet using a binocular microscope. A sample of 300 leaflets taken on May 20, 1968, two weeks before the first
TABLe 19

NET RATE OF GROWTH PER GENERATION FOR UNTREATED (CHECK) POPULATIONS OF THE TWO-SPOTTED MITE ON THE GOLDSMITH STRAWBERRY VARIETY (FIELD STUDY 2)

\begin{tabular}{c|c|c}
\hline $\begin{array}{c}\text { Date of } \\
\text { count (1968) }\end{array}$ & $\begin{array}{c}\text { Average number } \\
\text { mites per leaflet* }\end{array}$ & $\begin{array}{c}\text { Rate of increase } \\
\text { per generation }\end{array}$ \\
\hline May $20 \ldots \ldots \ldots \ldots$ & 3.2 & $\ldots \ldots$ \\
June $3 \ldots \ldots \ldots \ldots$ & 24.0 & $\ldots \ldots$ \\
June $17 \ldots \ldots \ldots$ & $13.5 \dagger$ & $4.1 \times\left(\mathrm{P}_{1}\right)$ \\
July $1 \ldots \ldots \ldots \ldots$ & 55.3 & $3.62 \times\left(\mathrm{F}_{1}\right)$ \\
July $15 \ldots \ldots \ldots \ldots$ & 199.9 & $0.1 \times\left(\mathrm{F}_{2}\right)$ \\
July $29 \ldots \ldots \ldots \ldots$ & 19.0 & $\ldots \ldots\left(\mathrm{F}_{3}\right)$ \\
August $12 \ldots \ldots \ldots$ & 34.7 & $\ldots$ \\
\hline
\end{tabular}

* Data represent an average from 20 leaflets from each of four replicates.

$\dagger$ The field on which the plot was situated was sprayed by aircraft on June 9,1968 , with mevinphos. The plot was covered with a plastic tarp during the application and for 12 hours thereafter, but a kill still resulted as evidenced in the population decline the following week. Therefore, rate of increase in the population is calculated beginning June 17, 1968 .

release showed a very low level of infestation. Of the 300 leaflets, 254 had no mites, while 23 had from one to five mites. A second sample taken the same day as the first release (June 3, 1968) revealed a mite population of just less than ten post-embryonic stages per leaflet. An analysis of variance was conducted on each set of data from every population count to determine if significant differences occurred between the various treatments.

\section{Mathematical models}

It was established from mite counts made on June 17, July 1, and July 15 that the check population underwent increases of 4.1-, 3.62-, and 0.1-fold per generation (table 19). A mathematical model was constructed for a population into which a 19:1 ratio of sterile-male releases were made (table 20). Models for unimpeded growth and a 90 per cent mortality per generation by a miticide were made. Only the total populations for each generation of these two models are listed in the last two lines of table 20 for comparison. Assumptions made for previously constructed models (field study 1) were applied to the above models. 


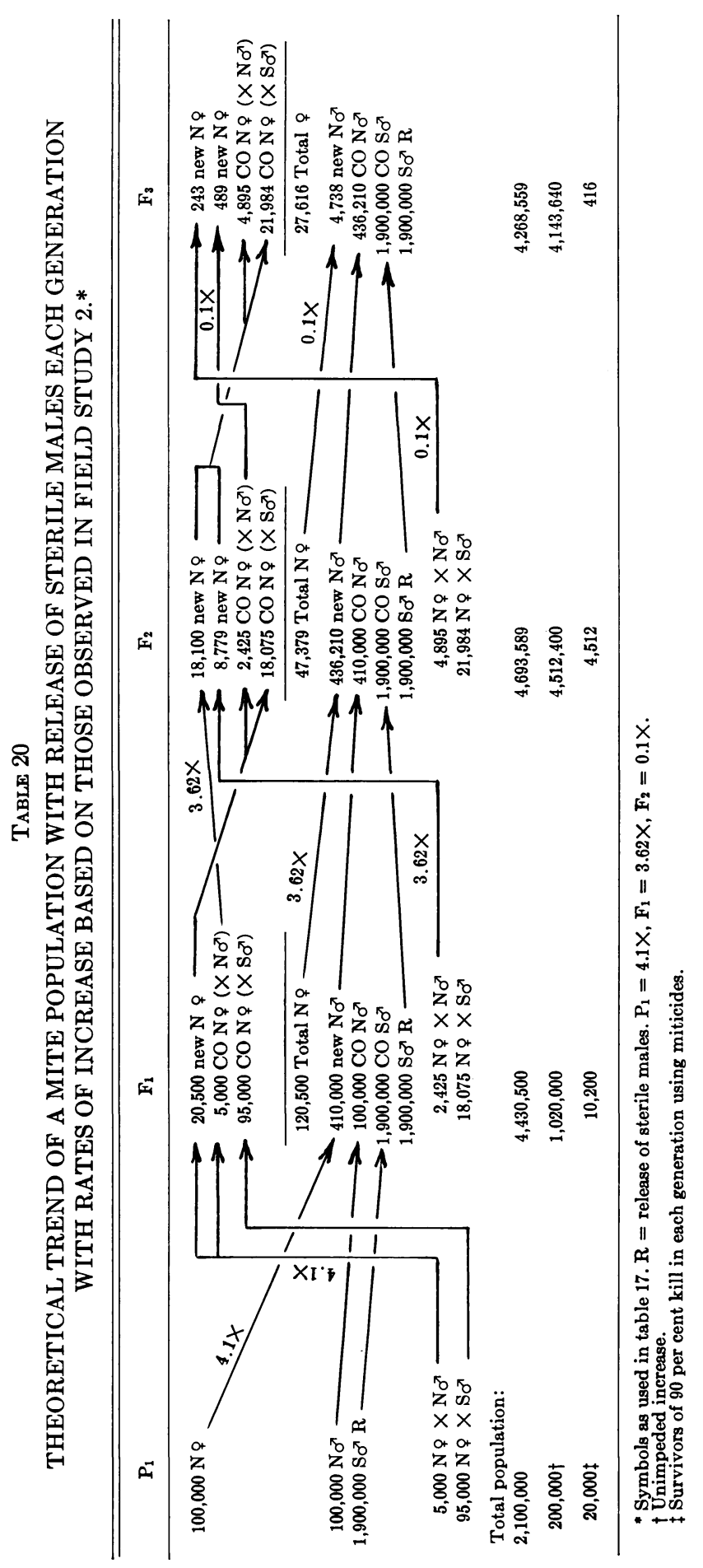


TABLE 21

MEAN NUMBERS OF SPIDER MITES PER STRAWBERRY LEAFLET FROM EACH OF FOUR DIFFERENT TREATMENTS COMPARED*

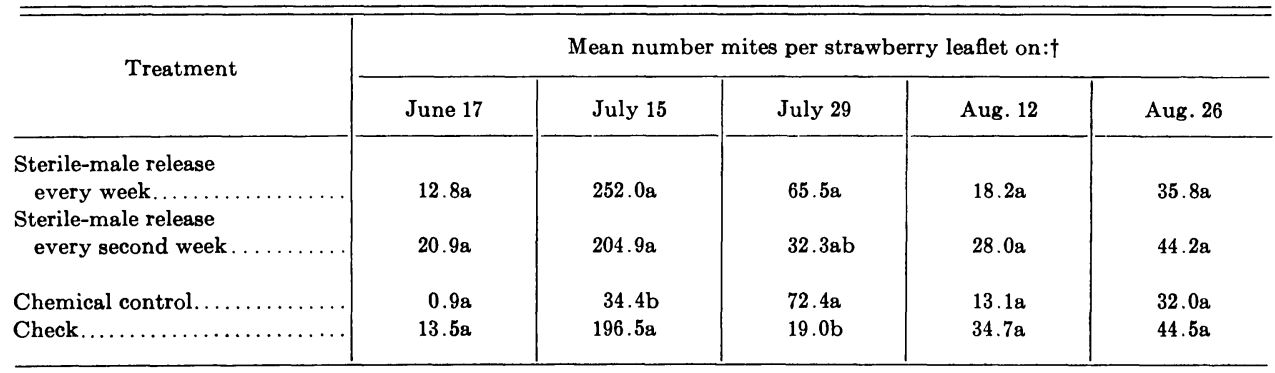

* Average for 20 leaflets from each of four replicates.

$\dagger$ On each date, entries followed by the same letter are not significantly different from each other at the 1 per cent level.

\section{Results and discussion}

Table 21 presents a summary of the mean number of mites per leaflet from each treatment for every count. The mean represents an average for 20 leaflets from each of the four replicates. An analysis of variance and Duncan's Multiple Range Test were applied to each set of data to detect significant differences at the 1 per cent level among treatments on each sampling date.

Although a difference of about 20 mites per leaflet occurred between the highest and lowest treatment means on June 17, there were no significant differences between treatments. This is due to extreme variations in the numbers of mites for replicates of the same treatment. Population counts on July 15 indicated that the chemical applications kept the mite population significantly lower than the sterile-male release plots or the check. However, two weeks later (July 29), the population levels declined in all treatments except the chemical treatment, in which they increased. Declining populations first reached a level of about 200 to 250 mites per leaflet and then underwent a marked decrease to less than 15 mites per leaflet in two to three weeks. When the population was at its highest level, the females appeared to lay fewer eggs. This physiological response may be in- duced by any one of several factors: an overcrowded habitat, lack of a suitable oviposition site, production of certain biochemical entities harmful to the mites in response to their feeding, or a lack of adequate nutrition in the host plant. (No insect or mite predators were observed before, during, or after the decline.) The population in the untreated check of the first field trial responded in the same manner (table 14). Counts of August 12 and 26 (table 21) show all four treatments remaining at a moderate level of infestation (13 to 44 mites per leaflet) with no significant differences between treatments. An analysis of variance conducted on the sum of the treatment means from all five dates showed that chemical treatment resulted in significantly fewer mites than the other three treatments. However, there were no statistically significant differences in total strawberry yields between treatments. Subsequent studies concerning the economic threshold suggest that this level is considerably below the numbers maintained by the chemical control. This would explain the lack of significant differences in production between the chemical control and both the sterile-male releases and untreated check. The accumulative crop yield from each treatment and the mean mite population per leaflet (table 21) are illustrated in figure 7. 


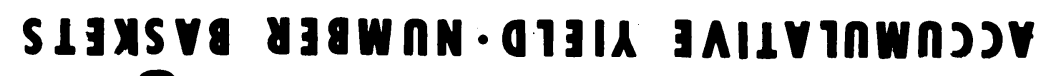

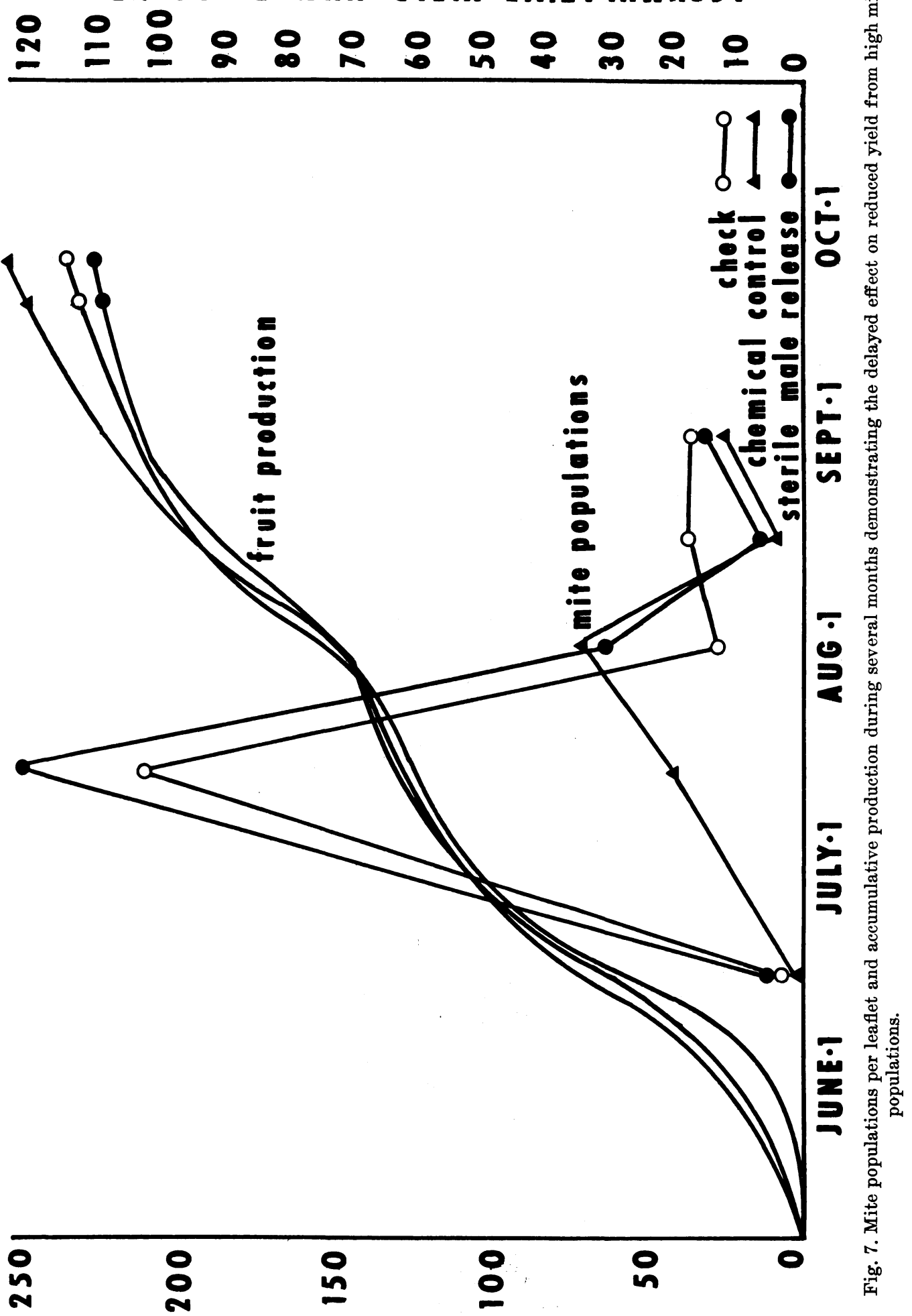

li1gVi gad Sallw gagwnN NVaw 
Our tests showed that the release of sterile males did not effectively suppress or control mite populations. The mathematical model describing the 19:1 release ratio (table 20 ) showed an increase in the total $F_{1}$ population of more than twice the $\mathrm{P}_{1}$. The $\mathrm{F}_{2}$ and $\mathrm{F}_{3}$ total populations were not very different from that of the $F_{1}$. After the slight increase in total female mites from the $P_{1}$ to $F_{1}$ generation, there were large decreases in the $\mathrm{F}_{2}$ and $\mathrm{F}_{3}$. Actually the increasing proportions of males in the $\mathrm{F}_{2}$ and $\mathrm{F}_{3}$ generation were due to the release and carryover of sterile males. Thus, the model is in agreement with the observation that plant damage was not as severe as when equal numbers of mites of both sexes were released. This is probably due to greater feeding activity by the females. A comparatively high rate of increase (tables 16 and 17) completely nullified the beneficial effects of either the release of sterile mites or the 90 per cent miticidal reduction in mite population in the $\mathrm{P}_{1}$. In contrast, field study 2 , with a $4.1 \times$ and $3.6 \times$ increase per generation, showed a declining population resulting from the 90 per cent miticidal control treatments.

In addition to the considerations listed above, and the arrhenotokous parthenogenetic nature of the two-spotted spider mite, another significant reason for lack of success of the sterile-male release lies in the clumping or aggregative character of the mite populations (i.e. negative binomial distribution) at the time of sterile-male releases. One leaflet may have a high population, while the adjacent leaflets (of the same or surrounding plants) have few or possibly no mites. For effective control by the sterile-male technique, one would then have to release a 19:1 ratio based on the highest number of mites per leaflet and not on the average number per leaflet from a large sample.

\section{ACKNOWLEDGMENTS}

The writers gratefully acknowledge financial assistance and use of laboratory and field facilities of Driscoll Strawberry Associates, Inc. We thank the Department of Pomology, University of California, Davis, for the use of the Mark II irradiator, R. Stallman, Department of Pomology, for operating the irradiator, and J. Stone, Department of Radiobiology for conducting thermoluminescence dosimetry studies.

\section{LITERATURE CITED}

Alexander, $\mathrm{P}$.

1965. Atomic radiation and life. 2nd ed. London and Tonbridge: Whitefriars Press Ltd. $296 \mathrm{pp}$.

Andrew artha, H. G., and L. C. Birch

1954. The distribution and abundance of animals. Chicago: The University of Chicago Press. $782 \mathrm{pp}$.

BAKER, W. K., and E. voN HALLE

1954. The production of dominant lethals in Drosophila by fast neutrons from cyclotron irradiation and nuclear detonations. Science 119:46-49.

BAXTer, R. C., and L. W. TuTTLE

1957. Life-span shortening in irradiated Drosophila (Abstract). Radiation Res. 7:303.

Beavers, J. B., R. B. Hampton, H. H. ToBA, and D. S. Moreno

1971. Some effects of gamma irradiation or the chemosterilant, tepa, on the citrus red mite and its progeny. Jour. Econ. Ent. 64:72-5.

Berryman, A. A.

1967. Mathematical description of the sterile male principle. Canad. Ent. 99:858-65. 
BlaUvelt, W. E.

1945. The internal morphology of the common red spider mite (Tetranychus telarius (Linn.)). Cornell University Agric. Exp. Sta. Mem. 270, 35 pp.

BuIss, C. I., and R. A. Fisher

1953. Fitting the negative binomial distribution to biological data and note on the efficient fitting of the negative binomial. Biometrics 9:176-200.

BOUDREAUX, H. B.

1958. The effect of relative humidity on egg-laying, hatching, and survival in various spider mites. Jour. Insect Physiol. 2:65-72.

1963. Biological aspects of some phytophagous mites. Ann. Rev. Ent. 8:137-54.

Boudreaux, H. B., and G. Dosse

1963. Concerning the names of some common spider mites. In: Naegele, J. A., ed., Adv. in Acarology 1:350-64.

BURkholder, W. E., E. W. Tilton, and R. R. CogBurN

1966. Effects of gamma radiation on the grain mite, Acarus siro. Jour. Econ. Ent. 59:976-80.

CAGLE, L. R.

1949. Life history of the two-spotted spider mite. Virg. Agric. Exp. Sta. Tech. Bul. 113, 31 pp.

Clark, A. M., M. A. Rubin, and D. Fluke

1957. Alpha-particle-induced dominant lethal in the mature sperm of Habrobracon. Radiation Res. 7:461-2.

Dosse, G., and M. LANGENSCHEIDT

1964. Morphologische, biologische, Untersuchungenan Hybriden aus dem Tetranychus urticaecinnabarinus Komplex. (Acari-Tetranychidae). Zeitschr. fuer. Angew. Ent. 54:349-59.

Evans, H. J.

1962. Chromosome aberrations induced by ionizing radiations. Int. Rev. Cytol. 13:221-321.

GASSER, R.

1951. Zur kenntnis der gemeinen spinnmilbe Tetranychus urticae Koch. Bull. Soc. Ent. Suisse 24:217-62.

GIBBS, K. E., and F. O. Morrison

1959. The cuticle of the two-spotted mite, Tetranychus telarius (Linnaeus) (Acarina: Tetranychidae). Canad. Jour. Zool. 37:633-37.

Grosch, D. S.

1962. Entomological aspects of radiation as related to genetics and physiology. In: Ann. Rev. Ent. 7:81-106.

1965a. Biological effects of radiations. New York: Blaisdell Publ. Co. 293 pp.

HELLE, W.

1967. Fertilization in the two-spotted spider mite (Tetranychus urticae: Acari.). Ent. Exptl. and Appl. 10:103-10.

HeLle, W., and H. R. Boland

1967. Karotypes and sex-determination in spider mites (Tetranychus). Genetics 38:43-53.

HENNEBERRY, T. J.

1964. Effects of gamma radiation on the fertility of the two-spotted spider mite and its progeny. Jour. Econ. Ent. 57:672-74.

HEwITT, R. B.

1963. Early embryology of the two-spotted mite Tetranychus telarius (L.) (Acarina: Tetranychidae). Ph.D. thesis, Univ. of Calif., Davis. 76 pp.

Huffaker, C. B., M. VAN DE VRIE, and J. A. MCMURTRY

1969. The ecology of tetranychid mites and their natural control. Ann. Rev. Ent. 14:125-74.

1970. Ecology of tetranychid mites and their natural enemies: A review. II. Tetranychid populations and their possible control by predators: An evaluation. Hilgardia 40:391458.

Husseiny, M. M., and H. F. MADSEN

1964. Sterilization of the navel orangeworm, Paramyelois transitella (Walker), by gamma radiation. (Lepidoptera: Phycitidae). Hilgardia 36(3) :113-37.

International Atomic Energy Agency

1962. Radioisotopes and ionizing radiations in entomology. Bibliographical Series No. 9 (1950-1960). Vienna: IAEA. 414 pp.

1965. Radioisotopes and ionizing radiations in entomology. Bibliographical Series No. 15 (1961-1963). Vienna: IAEA. 564 pp.

1967. Radioisotopes and ionizing radiations in entomology. Bibliographical Series No. 24 (1964-1965). Vienna: IAEA. 454 pp. 
KEH, B.

1952. Mating experiments with the two-spotted spider mite complex. Jour. Econ. Ent. 45:308-12.

Kensler, D. L., JR., and H. T. STREU

1967. A biological and toxicological study of strains of two-spotted spider mites. Jour. Econ. Ent. 60:1073-78.

KNIPLING, E. F.

1955. Possibilities of insect control or eradication through the use of sexually sterile males. Jour. Econ. Ent. 48:459-62.

1959. Sterile male method of population control. Science 130:902-04.

1960. Use of insects for their own destruction. Jour. Econ. Ent. 53:415-20.

1964. The potential role of the sterility method for insect population control with special reference to combining this method with conventional methods. U. S. Dept. Agric., ARS 33-98, Nov. 1964, $54 \mathrm{pp}$.

LABrecque, G. C., and J. C. KeLler (eds.)

1965. Advances in insect population control by the sterile male technique. Tech. Rep. Series No. 44. Vienna: IAEA, $79 \mathrm{pp}$.

LaChance, L. E.

1967. The induction of dominant lethal mutations in insects by ionizing radiation and chemicals as related to the sterile male technique of insect control. In: Genetics of insect vectors of disease. Wright, J., R. Pal (eds.). Amsterdam: Elsevier Press. Chap. 21.

LaChance, L. E., C. H. Schmidt, and R. C. Bushland

1967. In: Pest control (Kilgore, W. W., and R. L. Doutt). New York: Academic Press, pp. 147-96.

LaChance, L. E., D. T. North, and W. KLassen

1968. Cytogenic and cellular basis of chemically induced sterility in insects. In: Principles of insect chemosterilization (LaBrecque, G. C., and C. N. Smith). New York: Appleton-

LAING, J. E. Century-Crofts, pp. 99-157.

1969. Life history and life table of Tetranychus urticae Koch. Acarologia 11:32-42.

LEHR, R., and F. F. SMITH

1957. The reproductive capacity of the two-spotted spider mite complex. Jour. Econ. Ent. 50:634-36.

LINDQUIST, A. W. (ed.)

1963. Insect population control by the sterile male technique. Tech. Rep. Series No. 21. Vienna: IAEA. 59 pp.

MoEnRoE, W. D.

1961. The control of water loss by the two-spotted spider mite. Ann. Ent. Soc. Amer. 54:883-87.

MANDL, A. M.

1964. The radiosensitivity of germ cells. Biol. Rev., Cambridge Phil. Soc. 39:288-371.

MORRIS, R. F.

1954. A sequential sampling technique for spruce budworm egg surveys. Canad. Jour. Zool. 32:302-13.

MULLER, H. J.

1927. Artificial transmutation of the gene. Science 66:84-7.

MUNGER, F., and J. E. GILMORE

1963. Equipment and technique used in rearing and testing the citrus red mite. In: Adv. in Acarology (Naegele, J. A.) 1:157-68. Ithaca, New York: Comstock Pub. Assoc., Cornell University Press.

NeLson, R. D.

1968. Effects of gamma radiation on the biology and population suppression of the two-spotted spider mite, Tetranychus urticae Koch. Ph.D. thesis, Univ. Calif., Davis. 110 pp.

NICKEL, J. L.

1960. Temperature and humidity relationships of Tetranychus desertorum Banks with special reference to distribution. Hilgardia 30:41-100.

Pizzarello, D. J., and R. L., Witcofski

1967. Basic radiation biology. Philadelphia: Lea and Febiger. 301 pp.

Proverbs, M. D.

1969. Induced sterilization and control of insects. Ann. Rev. Ent. 14:81-102. 
Romani, R. J., E. C. Maxie, C. O. Hesse, and N. F. Sommer

1962. Cobalt-60 gamma ray irradiator opens new doors to biological research at Davis. Calif. Agric. 16:1-4.

Romani, R. J., B. J. Robinson, H. L. RAe, E. C. Maxie, and N. F. Sommer

1963. Fruit irradiation-physical methods. Radiation Botany 3:345-50.

SCHRADER, F.

1923. Haploidie bei einer Spinnmilbe. Archives D. Anatomie Microscopique et de Morphologie Experimentale 97:610-22.

SMITH, F. F., A. L. BOSWELL, and T. J. HENNEBERRY

1965. Chemosterilant treatment of two greenhouse spider mites. Jour. Econ. Ent. 58:98-103. SOBELS, F. H.

1963. Repair and differential radiosensitivity in developing germ cells of Drosophila males. In: Repair from genetic radiation damage and differential radiosensitivity in germ cells (F. H. Sobels, ed.). London: Pergamon Press. 454 pp.

Sparrow, A. H. (chairman)

1961. Fundamental aspects of radiosensitivity. Brookhaven Symposia in Biology, Vol. 14, $308 \mathrm{pp}$.

SPARROW, A. H.

1962. The role of the cell nucleus in determining radiosensitivity. Brookhaven Lecture Series 17:1-29.

STONE, W. E.

1963. Effects of ionizing radiation on insects and other arthropods. In: Radiation and radioisotopes applied to insects of agricultural importance. Vienna: IAEA, pp. 301-12.

TASHIRO, $\mathrm{H}$

1967. Self-watering acrylic cages for confining insects and mites on detached leaves. Jour. Econ. Ent. 60:354-56.

Toba, H. H., A. N. KIshabA, and D. T. NoRTH

1972. Reduction of populations of caged cabbage loopers by release of irradiated males. Jour. Econ. Ent. 65:405-11.

VIRKKI, N.

1965. Insect gametogenesis as a target. Agric. Sci. Rev. 3:24-37.

VON BORSTEL, K. C.

1963. Effects of radiation on germ cells of insects: dominant lethals, gamete inactivation, and gonial cell killing. In: Radiation and radioisotopes applied to insects of agricultural importance. Vienna: IAEA, pp. 367-85.

WATSON, T. F.

1964. Influence of host plant condition on population increase of Tetranychus telarius (Linnaeus) (Acarina: Tetranychidae). Hilgardia 35:273-322.

WhaRTon, D. R. A., and M. L. WharToN

1959. The effect of radiation on the longevity of the cockroach, Periplaneta americama, as affected by dose, age, sex, and food intake. Radiation Res. 11:600-15.

Whiting, A. R.

1961. Temperature effects on lethal mutation rates of Habrobracon oocytes X-irradiated in first meiotic metaphase. Genetics 46:811-16.

WURGLER, F. E., H. ULRICH, and A. SCHNEIDER-MiNDER

1963. Variation of radiosensitivity during meiosis and early cleavage in newly laid eggs of Drosophila melanogaster. In: Repair from genetic radiation damage and differential radiosensitivity in germ cells (F. H. Sobels, ed.). London: Pergamon Press. 454 pp.

To simplify the information, it is sometimes necessary to use trade names of products or equipment. No endorsement of named products is intended nor is criticism implied of similar products not mentioned. 


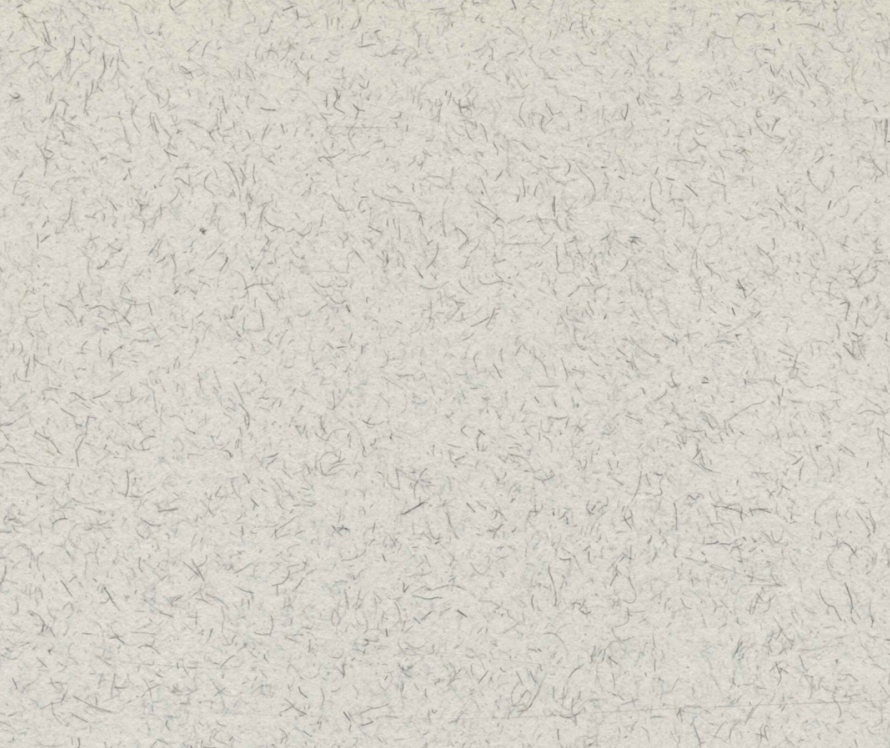

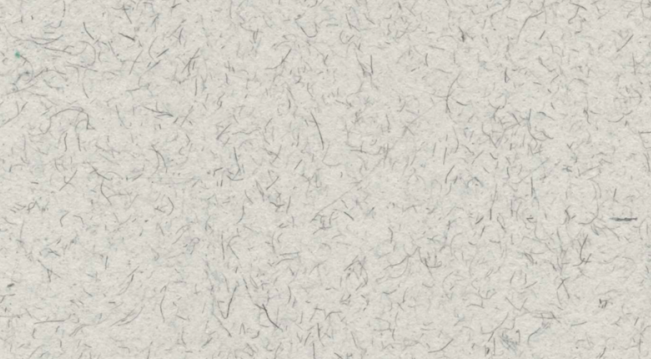

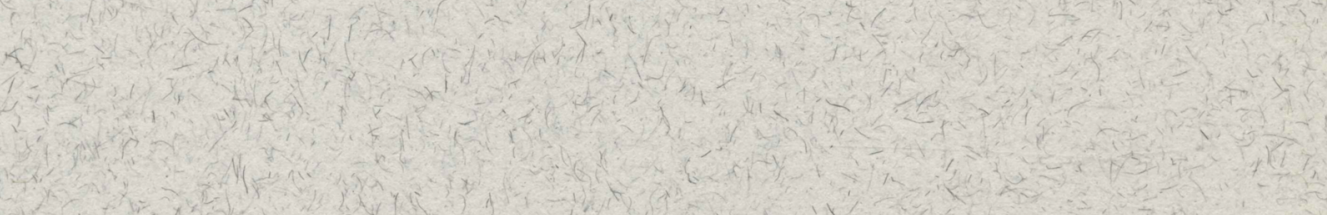

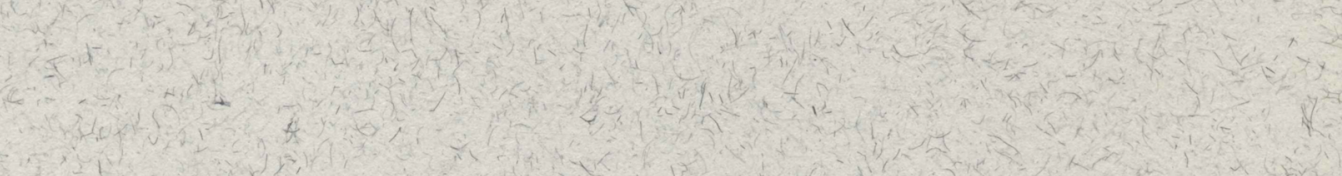


The journal HILGARDIA is published at irregular intervals, in volumes of about 650 to 700 pages. The number of issues per volume varies.

Single copies of any issue may be obtained free, as long as the supply lasts; please request by volume and issue number from:

\section{Agricultural Publications \\ University of California \\ Berkeley, California 94720}

The limit to nonresidents of California is 10 separate titles. The limit to California residents is 20 separate titles.

The journal will he sent regularly to libraries, schools, or institutions in one of the following ways:

1. In exchange for similar published material on research.

2. As a gift to qualified repusitory libraries only.

3. On a subscription hasis $\$ \mathbf{\$ 7 . 5 0}$ a year paid in advance. All subscriptions will be started with the first number issued during a calendar year. Subscribers starting during any given year will he sent back numbers to the first of that year and will be billed for the ensuing year the following January. Make checks or money orders payable to The Regents of The University of California; send payment with order to Agricultural Publications at above address. 